\title{
Type I and II Interferons in the Anti-Tumor Immune Response
}

\author{
Sarah E. Fenton ${ }^{1,2}$, Diana Saleiro ${ }^{1,2} \mathbb{D}$ and Leonidas C. Platanias ${ }^{1,2,3, *}$ \\ 1 Robert H. Lurie Comprehensive Cancer Center of Northwestern University, Chicago, IL 60611, USA; \\ sarah.fenton@northwestern.edu (S.E.F.); diana.saleiro@northwestern.edu (D.S.) \\ 2 Division of Hematology-Oncology, Department of Medicine, Feinberg School of Medicine, \\ Northwestern University, Chicago, IL 60611, USA \\ 3 Department of Medicine, Jesse Brown Veterans Affairs Medical Center, Chicago, IL 60612, USA \\ * Correspondence: 1-platanias@northwestern.edu
}

Citation: Fenton, S.E.; Saleiro, D.; Platanias, L.C. Type I and II Interferons in the Anti-Tumor Immune Response. Cancers 2021, 13, 1037. https://doi.org/10.3390/ cancers13051037

Academic Editor: David Wong

Received: 2 February 2021

Accepted: 23 February 2021

Published: 2 March 2021

Publisher's Note: MDPI stays neutral with regard to jurisdictional claims in published maps and institutional affiliations.

Copyright: (c) 2021 by the authors. Licensee MDPI, Basel, Switzerland. This article is an open access article distributed under the terms and conditions of the Creative Commons Attribution (CC BY) license (https:// creativecommons.org/licenses/by/ $4.0 /)$.
Simple Summary: Interferons are cytokines that play key roles in the activation of cellular components of the immune response, such as dendritic cells, macrophages and T cells. Generally, these cytokines promote anti-tumor immune responses, but under some circumstances, prolonged exposure to them can lead to suppression of the immune response. This review focuses on the immunostimulatory versus immunosuppressive roles of interferons and the mechanisms mediating such effects on both malignant cells and cells of the immune system.

\begin{abstract}
The interferons (IFNs) are essential components of the immune response against infections and malignancies. IFNs are potent promoters of the anti-tumor response, but there is also evidence that feedback mechanisms regulated by IFNs negatively control immune responses to avoid hyper-activation and limit inflammation. This balance of responses plays an important role in cancer surveillance, immunoediting and response to anticancer therapeutic approaches. Here we review the roles of both type I and type II IFNs on the control of the immune response against malignancies in the context of effects on both malignant cells and cells of the immune system in the tumor microenvironment.
\end{abstract}

Keywords: interferons; cancer; dendritic cell; macrophage; T cell; cancer immunoediting

\section{Introduction}

The intersections between malignancy and the immune system and the communications between malignant cells and cells of the immune system have emerged as central to understanding oncogenesis and tumor progression [1]. With the introduction of immunomodulatory anticancer therapies such as antibodies against PD-L1 and CTLA-4, as well as an increased understanding of the importance of immune activation in the response to chemotherapeutic agents, research into immunity within the tumor microenvironment (TME) has continued to evolve [2]. Central to this progress has been the hypothesis of cancer immunoediting. This model posits that the immune system initially defends the host against cancer development [3]. However, some malignant cells can survive this protective immune response, resulting in their escape and continued tumor growth $[4,5]$. Thus, immune pressure on malignant cells can initially induce tumor cell death, but later allow tumor growth by reducing the ability of the host to stimulate a protective immune response in favor of a quiescent TME. Signaling by the interferon (IFN) receptors has been shown to be central to both mechanisms of immune surveillance and escape $[4,5]$.

The IFNs evolved to counter viral and bacterial insults by activating the adaptive immune response and reducing the propagation of infection [6]. IFNs also activate negative feedback signaling mechanisms that aim to prevent excess IFN-mediated inflammation and tissue damage $[7,8]$. This dual role for IFN signaling is critical for the optimal regulation of responses to infection and antineoplastic effects, but it is also coopted by malignant cells to 
allow ongoing survival and growth [4]. Understanding the mechanisms of actions of IFNs and how they alter the function of specific cell populations within the TME is important for the development of novel immune therapies. Here we discuss the role of type I and type II IFNs at the level of individual immune cell populations and malignant cells and review the mechanisms by which IFNs regulate anti-tumor immune responses.

\section{Interferon Production and Signaling}

IFNs are released predominantly by immune and stromal cells to effect a multitude of cellular responses $[9,10]$. These cytokines are divided into three classes, type I, type II and type III IFNs, and utilize the type I, II and III IFN receptors, respectively [11]. Upon target cell receptor binding, IFNs induce the expression of unique genes, called IFN-stimulated genes (ISGs), which ultimately mediate IFN-dependent biological effects [12,13]. As not much is known yet about the roles of type III IFNs in the TME, this review will focus on type I and type II IFNs.

\subsection{Type I Interferons}

Type I IFNs (IFNIs) are the largest subgroup of IFNs, and include interferon $\alpha$ (IFN $\alpha$ ), interferon $\beta$ (IFN $\beta$ ), interferon $\varepsilon$, interferon $k$ and interferon $\omega$ in humans, as well as interferon $\delta$ and interferon $\tau$ in other mammals [14-16]. IFNIs signal via the type I IFN receptor (IFNAR) that is expressed on nearly every cell type and is composed of the receptor subunits IFNAR1 and IFNAR2 $[17,18]$. In malignant cells, nuclear leakage of DNA and other damage-associated molecular patterns (DAMPs) into the cytosol can be sensed by pattern recognition receptors (PRRs) such as retinoic acid-inducible gene I (RIG-I), DNA-Dependent Activator of IFN-Regulatory Factors and IFI16 to stimulate IFNI production [18]. DAMPs released into the TME interact with endosomal Toll-like receptors (TLRs) in immune cells to activate IFNI production [19]. Additionally, in the cytoplasmic compartment of immune cells, tumor DNA binds cyclic GMP-AMP synthase (cGAS) and acts in conjunction with Stimulator of Interferon Genes (STING) signaling to initiate IFNI production [20-22]. IFNI binds to its receptor at the cell surface, activating several signaling pathways. These include the Janus Kinase/Signal Transducer and Activator of Transcription (JAK/STAT) pathways, where complexes of activated STAT proteins translocate to the nucleus and initiate transcription of ISGs by binding to specific promoter interferon-sensitive response elements (ISREs) and IFN $\gamma$-activated site (GAS) elements [23]. Other activated pathways include those associated with mitogen-activated protein kinases (MAPKs) (particularly the p38 MAPK signaling cascade) and phosphoinositide 3-kinase (PI3K)/mTOR cascades $[9,10,24]$.

\subsection{Type II Interferon}

The type II IFN class (IFNII) is composed of only one member, IFN gamma (IFN $\gamma$ ) [10]. IFN $\gamma$ is mainly produced by natural killer cells (NKs), CD8+ T cells, CD4+ T helper type 1 (Th1) cells and by a specific subtype of macrophages and dendritic cells (DCs) [7]. IFN $\gamma$ binds to the type II IFN receptor (IFNGR) which is composed of two subunits, IFNGR1 and IFNGR2 [25]. Following IFNGR dimerization, the JAK/STAT pathway is activated, altering gene expression through activation and binding of different STAT1 and/or STAT3 complexes to GAS elements in the promoter region of ISGs [10]. IFNII signaling also activates non-STAT pathways that play important roles in eliciting biological responses, including MAPK, PI3K, JNK, CamKII and NF-KB [26].

\section{Effects of Interferons on the Tumor Microenvironment}

\subsection{Dendritic Cells}

Dendritic cells (DCs) present antigens and produce cytokines to activate other immune cell populations [27]. In the TME, contact with tumor derived DNA and other DAMPs promotes DC activation and IFNI production through the STING/IFN-regulatory factor (IRF) 3 and/or TLR/IRF pathways $[17,22]$. Exposure to IFNI is then required for full 
maturation of DCs, characterized by the expression of the costimulatory molecules CD40, CD80 and CD86 and major histocompatibility complex (MHC) class II molecules [28,29]. Additionally, IFNI exposure improves the ability of DCs to present tumor antigens on their cell surface [30-33] and promotes DC migratory capabilities [34]. Thus, IFNI also increases the ability of DCs to recruit and activate CD4+ Th1 and CD8+ T cells to the TME [31,35]. Additionally, DCs exposed to IFNI produce high levels of interleukin 12 (IL-12) and IL-15, stimulating further downstream immune activation $[36,37]$.

Plasmacytoid dendritic cells (pDCs) are a specialized subset of DCs that release high levels of IFNI in response to foreign antigens and link innate and adaptive immunity [38]. Because pDCs are capable of rapidly secreting much higher levels of IFNI than conventional DCs due to constitutive expression of IRF7, they are thought to play a critical role in the initial immune response against tumor cells [29,39]. In an orthotopic in vivo mammary tumor model, administration of TLR7 ligand was shown to activate tumor-associated pDCs, inducing tumor regression. Neutralization of IFNI activity prevented this response [40]. However, some studies of patient tumors have found that $\mathrm{pDC}$ tumor infiltration correlates with poor outcomes [41]. This may be due to $\mathrm{pDC}$ co-localization with regulatory T cells (Tregs) in the TME, which decreases responsiveness of tumor infiltrating pDCs, reducing IFN $\alpha$ production $[29,42]$.

Similar to IFNI, IFN $\gamma$ acts on DCs inducing the expression of cytokines, costimulatory and MHC molecules and proteins involved in the antigen-presentation process, ultimately leading to activation of other immune cells [43-45]. IFN $\gamma$-induced STAT1-dependent activation of IRF1 regulates expression of the MHC class I locus, while the IFN $\gamma$-induced ISG CIITA upregulates expression of MHC class II genes [45]. IFN $\gamma$ also changes the composition of the proteasome, altering its function to a specialized immunoproteasome, which increases the amount and variety of peptides available for antigen presentation by MHC class I proteins at the surface of DCs [45]. In an in vivo study, co-injection of IFN $\gamma$ and TLR ligands resulted in higher DC activation and migration from the site of immunization to the draining lymph nodes and a consequent increase in T cell activity [46].

Although IFNs promote migration and activation of DCs in the TME initially, at later stages sustained signaling through either the IFNI or IFNII receptors can lead to suppressive effects on DCs. Chronic or prolonged exposure to IFNIs can impede DC differentiation and homeostasis and upregulate immunosuppressive molecules such as PD-L1 on DCs [47-49]. Moreover, prolonged exposure to IFN $\gamma$ induces an IDO-dependent switch of immunogenic DCs to tolerogenic DCs, which favor activation of Tregs [50-52]. Notably, GSK-3 $\beta$ inhibitors block IFN $\gamma$-mediated IDO expression, enhancing the activity of DC-based vaccines in vivo [53]. Overall, these findings underscore the importance of a better understanding of both IFN-dependent stimulatory and suppressive mechanisms in DCs (Figures 1 and 2) in order to develop novel immunotherapeutic approaches.

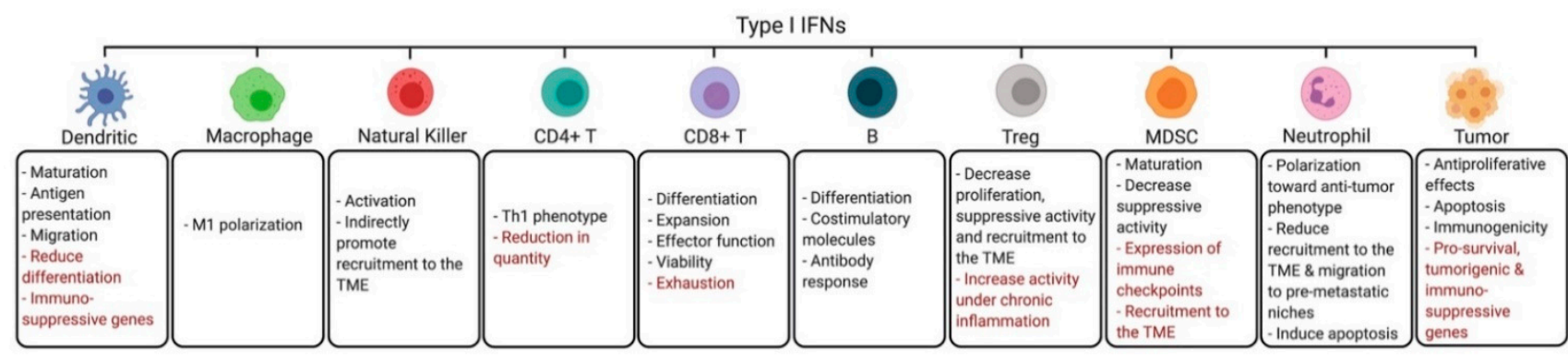

Figure 1. Effects of type I interferons (IFNIs) on malignant cells and cells of the immune system. Exposure to type I IFNs alters the function of target cells within the tumor microenvironment (TME) in ways that promote anti-tumor effects (black) or counter such effects (red). 


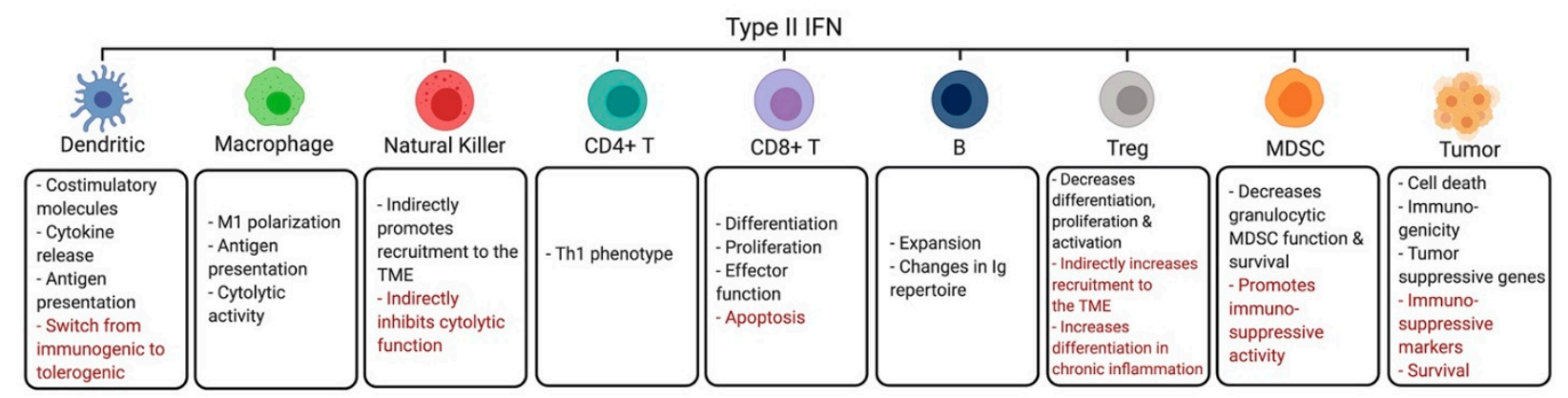

Figure 2. Effects of the type II interferon (IFNII) on malignant cells and different types of immune cells. Exposure to type II IFN alters the function of the tumor and immune cells within the TME in ways that promote anti-tumor effects (black) or counter such effects (red).

Clinically, interest in manufactured DCs and DC-stimulating/based therapies has been growing [54]. Studies in acute myeloid leukemia (AML) models suggest that monocytes reprogrammed with lentiviral vectors to co-express GM-CSF, IFN $\alpha 2$ and antigens differentiate into induced DCs that potently activate anti-tumor $\mathrm{T}$ and $\mathrm{B}$ cells, providing a potential new therapeutic approach to address minimal residual disease following chemotherapy for AML patients [55]. In pre-clinical breast cancer models, restoration of IFNI activity in the TME via administration of TLR agonists increases activation of DCs and reduces mammary tumor growth [56]. As research into DC-based treatments has continued, IFN $\alpha$ exposure has been identified as an important step to allow vigorous immune responses following treatment and to improve efficacy of anti-tumor vaccines [57-60]. Finally, several clinical trials are currently underway to study the outcomes of STING agonists alone or in combination therapies [61]. These agonists induce IFNI production, which ultimately activates IFNI signaling in multiple components of the immune system, including DCs [62].

\subsection{Macrophages}

Macrophages phagocytize cellular debris to act as antigen presenting cells and produce cytokines such as TNF $\alpha$ and IL-6 in response to foreign materials and exogenous stimuli [63]. Both IFNIs and IFN $\gamma$ increase macrophage activity by polarizing immature monocytes into a mature anti-tumor M1 phenotype [64,65]. More specifically, IFN $\gamma$ upregulates expression of MHC molecules at the cell surface of macrophages and controls phagosome functions, increasing the repertoire of antigens available for presentation [45,64,66-69]. Together, these changes facilitate macrophage-mediated activation of $\mathrm{T}$ cells and the adaptive immune response [70].

In preclinical breast cancer models, transplantation of engineered TIE2-expressing macrophages that express IFN $\alpha$ reprograms the TME, inducing greater DC activation and CD8+ T cell cytotoxicity against tumor cells [71]. In another study, using a poorly immunogenic breast cancer mouse model, CSF-1R inhibitors were shown to block macrophage immunosuppressive activity by inducing IFNI signaling and expression of ISGs in the TME, synergizing with cisplatin therapy [72]. Novel therapeutic strategies are under development to enhance the anti-tumor functions of macrophages in the TME. One such approach involves blocking the binding between CD47 and signal regulatory protein alpha $(\mathrm{SIRP} \alpha)$, increasing tumor cell phagocytosis by macrophages [73,74]. Notably, a recent study demonstrated that the combination of CD47/SIRP $\alpha$ inhibition with activation of CD40 signaling using a SIRP $\alpha-\mathrm{Fc}-\mathrm{CD} 40 \mathrm{~L}$ fusion protein also enhances type I interferon responses in macrophages, increasing effector $\mathrm{T}$ cell activity, further blocking tumor growth [75]. In another study, Th1-derived IFN $\gamma$ was shown to increase macrophage-mediated antitumor cytotoxic activity by inducing the expression of proteases, granzyme $\mathrm{A} / \mathrm{B}$, and NK cell-related genes (e.g., NKG2D) and by promoting CXCL9 and CXCL10 secretion by macrophages [75]. In an ovarian cancer model, GM-CSF and IFN $\gamma$ produced by $\mathrm{T}$ cells expressing the chimeric NKG2D receptor increased activation of macrophages in the TME, IL12p40 production and antigen presentation by macrophages [76]. Additionally, IFN $\gamma$ was 
shown to induce macrophages to produce nitric oxide and increase direct lysis of cancer cells [77]. Thus, IFNs sustain an anti-tumor function of macrophages in the TME, driving changes that result in direct and immune-mediated tumor cell death (Figures 1 and 2).

\subsection{Natural Killer Cells}

In addition to DCs and macrophages, NKs form another critical component of the innate immune response $[78,79]$. Cytokines such as IFNI, IL-12 and IL-15 drive the activation of NKs [80,81]. Moreover, STING-induced IFNI-mediated expression of the ISGs CXCL10 and CCL5 in tumor and immune cells has also been shown to increase NK accumulation and activation in the TME [82]. Clinical interest in STING agonists has been growing, and the efficacy of these therapies may depend on the promoting effects of IFNI on anti-tumor NK cytotoxicity $[82,83]$. In a recent study using a preclinical model of triple negative breast cancer, specific deletion of Ifnar 1 expression in NK cells demonstrated a requirement for IFNI in NK cell-mediated tumor cell lysis [84]. Additionally, overexpression of IRF7 in prostate cancer cells inhibits bone metastases through IFNI-induced NK activation [85], while loss of host IFNI receptor signaling in vivo blocks NK-mediated anti-tumor immune responses and results in increased cancer cell metastasis [86-88]. Thus, IFNI plays an important role in regulating the induction of NK cytotoxic and anti-tumor activities in the TME [86]. It is remarkable that in mice with chronic viral infections, sustained activation of IFNI signals results in increased immunosurveillance against malignant cells by increasing the cytolytic function of NKs [89]. These studies suggest that NKs play an important role in immune activation and immune-mediated cell death within the TME and IFNIs are required for this response (Figure 1).

In IFNGR knockout mice less NKs are present in the TME, and this correlates with decreased survival following tumor implantation [90]. These findings were reversible in mice co-injected with recombinant IFN $\gamma$ protein and malignant cells via up-regulation of CXCR3 ligands in the tumor cells, demonstrating that IFN $\gamma$ is required for recruitment of NKs to the TME [90]. In contrast, IFN $\gamma$ was shown to induce PD-L1 expression on tumor cells, reducing their susceptibility to NK cytotoxicity [91]. Thus, depending on the effect of IFN $\gamma$ exposure on malignant cells, these can be more or less susceptible to NK-cell induced tumor lysis (Figure 2) [90-92].

\subsection{CD4+ Helper T Cells}

CD4+ Th1 cells function by releasing cytokines and modifying the immune response through activation of macrophages and other T cells [93]. Both IFNI and IFN $\gamma$ drive polarization of CD4+ T cells towards the anti-tumor Th1 phenotype, preventing differentiation into the protumor Th2 phenotype [29,45,94]. IFN $\gamma$ signals through STAT1 and downstream activation of T-bet, a regulator of the Th1 lineage that upregulates expression of the IL-12 receptor and IFN $\gamma$, creating a positive feedback loop [45,95] (Figure 2). On the other hand, in chronic viral infection models, high levels of IFNI have been correlated with reduced numbers of CD4+ T cells [96], suggesting that sustained IFNI exposure could deplete CD4+ $\mathrm{T}$ cells in the TME (Figure 1).

\subsection{CD8+ Cytotoxic T Cells}

CD8+ T cells interact with antigen-presenting cells to differentiate into effector CD8+ $\mathrm{T}$ cells, defined as cytotoxic T lymphocytes (CTLs) [97]. Upon antigen recognition and costimulation, a third signal (IFNI or IL-12) is necessary for further differentiation of naïve CD8+ T cells [98]. Moreover, IFNI also promotes the expansion, effector function and survival of CTLs [99-102]. Studies using human colorectal carcinoma cells have shown that tumor tissue and CTLs from colon cancer patients have decreased expression of IFNAR1 compared to normal colon tissue and CTLs from healthy donors [102,103]. Inactivation of IFNAR1 in CTLs was reported to limit their survival within the TME and undermine the efficacy of chimeric antigen receptor (CAR) $\mathrm{T}$ cell treatment in colon cancer models, while genetic stabilization of IFNAR1 improved CTL viability and response to both CAR 
T cell and anti-PD-1 therapy [103]. Additionally, IFNI was shown to activate STAT3 to promote expression of granzyme B in CTLs, enhancing their effector function [104]. It has been shown that resistance to anti-PD-1 therapy can be reversed with intratumoral administration of a TLR9 agonist, which results in IFNI production in the TME and a consequent increase in the number and quality of CD8+ T cells [105]. However, chronic IFNI signaling can ultimately induce an exhausted $\mathrm{T}$ cell phenotype through upregulation of the immune checkpoints PD-1, TIM-3 and LAG-3, suppressing the immune response $[29,106]$ (Figure 1).

IFN $\gamma$ induces the differentiation, activation, proliferation and survival of tumor specific CD8+ T cells, in part through the induction of regulatory genes including survivin and Ifi202 [107,108]. Following IFN $\gamma$ exposure, the cytolytic activity of CD8+ T cells is also increased through upregulation of granzymes and IL-2 receptor expression [45]. However, IFN $\gamma$ released into the TME may induce apoptosis of activated CD8+ T cells that express high levels of IFNGR, limiting immune activity [109] (Figure 2).

\subsection{B Cells}

IFNI enhances activation of B cells through upregulation of costimulatory molecules, leading to increased B cell responses $[110,111]$. Additionally, mice with B cells lacking the IFNI receptor present a reduced IFNI-mediated enhancement of the antibody response and isotype switching compared to mice with wild-type B cells [112]. TLR agonists, which induce intratumoral IFNI production, are currently being developed as a potential therapy against distinct malignancies [113,114]. The TLR9 agonist MGN1703 has been shown to promote a potent interferon response in the lymph nodes, increasing differentiation of $\mathrm{B}$ cells and activation of pDCs, NKs, and T cells [113].

IFN $\gamma$ inhibits B cell proliferation at early stages of activation prior to antigen exposure and at later stages, during B cell maturation. However, following primary antigen exposure, IFN $\gamma$ promotes B cell propagation [45]. Moreover, exposure to CD4+ Th1 cells and IFN $\gamma$ inhibits B cell class switching to IgE and promotes switching to IgG2, a class of antibodies that mediate antibody-dependent cytotoxicity [45]. Thus, IFN $\gamma$ plays a complex role on B cell function, depending on the stage of the cell's differentiation/activation. Interestingly, a CD11a hi Fc $\gamma$ RIII ${ }^{\text {hi }}$ B cell subpopulation was found to produce IFN $\gamma$ in early stages of the immune response against bacterial or viral infections or in response to TLR ligands, resulting in macrophage activation [115]. These results suggest a potential new role for these specific B cells in the TME. As activated B cells are capable of inducing comparable CTL-produced IFN $\gamma$ levels and tumor cell death as DCs [116], vaccines composed of B cells are under investigation [117]. For their success, it will be important to consider the effects of both IFNI and IFN $\gamma$ on these cells (Figures 1 and 2).

\subsection{Regulatory $T$ Cells}

CD4+CD25+FOXP3+ Tregs are a specialized subset of $\mathrm{T}$ cells that act to prevent damaging immune overactivity and maintain tolerance to self-antigens by inhibiting the function of effector T cells through the release of inhibitory cytokines, induction of $\mathrm{T}$ cell apoptosis and upregulation of immunosuppressive genes [118]. Exposure of Tregs to IFN $\alpha$ in vitro decreases their IL-2-induced proliferation and suppressive activity, ultimately promoting activation of CD4+ Th1 cells [119]. Studies using breast and colon cancer models have shown that IFN $\alpha$ diminishes Treg frequency within the TME [42,120,121]. Specific deletion of IFNAR in Tregs results in increased Treg proliferation and higher expression of PD-1 and CD44 on their cell surface, leading to decreased anti-tumor immune responses and tumor clearing in mouse models of colon cancer and melanoma [122]. Moreover, intratumoral IFNI production via administration of TLR or RIG-I-like receptor ligands inhibits CCL22 expression, a chemokine that serves to attract Tregs to the TME [123]. However, using a T cell-induced colitis model, it has been also shown that under inflammatory conditions IFNI maintains Foxp3 levels and Treg functions [124]. Likewise, under competitive or stress conditions IFNI was shown to sustain Treg development and function [125]. These studies 
suggest that IFNI could also support Treg immunosuppressive functions under certain conditions [124,125]. Thus, depending on the context, the interaction between IFNIs and Tregs could allow either the induction or suppression of an anti-tumor immune response (Figure 1).

Neuropilin-1 (Nrp1) is a transmembrane receptor that is critical for the function and stability of tumor infiltrating Tregs. Nrp1-/ - Tregs found within the TME produce IFN $\gamma$, which suppress the function of surrounding wild-type Tregs, increase anti-tumor immune activity. Thus, IFN $\gamma$ released by Nrp1-/ - Tregs results in increased fragility of other populations of intratumoral Tregs, increasing anti-PD1-driven anti-tumor immune responses [126]. IFN $\gamma$ also decreases differentiation of T cell precursors into Tregs and induces cell cycle arrest, preventing further proliferation [7,127]. In another study, IFN $\gamma$ administration reversed SEREX-defined self-Ag-mediated increase in generation/activation of Tregs, resulting in lower tumor incidence and metastasis in vivo [128]. Thus, IFN $\gamma$ exposure inhibits the differentiation, proliferation, activation and stability of Tregs in the TME. However, excessive IFN $\gamma$ production by CD4+ Th1 cells, caused by a deficiency in the deubiquitinase USP15, increases the number of Tregs and myeloid derived suppressor cells (MDSCs) in the TME through upregulation of PD-L1 and CXCL12 expression on CD45 negative non-immune cells. This ultimately increases the incidence of methylcholanthrene (MCA)-induced fibrosarcomas [129]. Additionally, in models of chronic inflammation, IFN $\gamma$ can drive the differentiation of specialized Tregs that inhibit CD4+ Th1 cells [108]. Together, these data suggest that IFN $\gamma$ directly or indirectly is capable of either stimulating or suppressing Treg function (Figure 2).

Potential therapeutic options including Treg depletion are under study [130]. Interestingly, inhibition of the histone H3K27 methyltransferase enhancer of zeste homolog 2 (EZH2) activity in Tregs induces Treg-mediated pro-inflammatory functions, enhancing IFN $\gamma$ production by CD8+ and CD4+ Th1 cells and anti-tumor immune responses [131].

\subsection{Myeloid Derived Suppressor Cells}

Tumors are often found to have increased infiltration by MDSCs [132]. MDSCs support an immunosuppressive TME by producing cytokines, such as IL-10, which promote activation of immunosuppressive cells (M2 macrophages and Tregs), by sequestering arginine or cysteine and by producing nitric oxide and reactive oxygen species to block $\mathrm{T}$ cell activation [133]. Moreover, IFNs upregulate the expression of the immune checkpoint PDL1 on the surface of MDSCs $[134,135]$. Resistance to radiation therapy has been associated with STING-dependent recruitment of MDSCs to the TME [136]. However, other reports have associated IFNI production with reduced MDSC accumulation and activity in the TME $[137,138]$. Interestingly, treatment with the TLR9 ligand CpG induces IFNI production by pDCs, which results in maturation of MDSCs in vitro [138]. Treatment with either CpG or IFNI in two tumor models resulted in decreased suppressive activity of MDSCs [138]. These data suggest that when IFNIs act directly on MDSCs, they decrease their inhibitory function, restoring the immune system's ability to eliminate malignant cells. As is often found when studying the anticancer immune response, exposure of MDSCs to IFNI can differentially regulate their response based on several factors, including the presence of other immune cells and inflammatory mediators (Figure 1).

IFN $\gamma$ produced by CD8+ T cells has been found to stimulate iNOS expression in monocytic MDSC (M-MDSC)-derived macrophages, promoting TLR2 ligand-dependent MMDSC-induced suppression of T cell activity [139]. In another study, in vitro co-treatment of bone marrow-derived MDSCs with lipopolysaccharide and IFN $\gamma$ increased MDSCmediated nitric oxide production and immunosuppressive activity, while blocking development of DCs [140]. Moreover, mast cells enhance the suppressive activity of M-MDSCs through an IFN $\gamma$-dependent mechanism [141]. IFN $\gamma$ promotes production of IL-10 and TGF- $\beta$ by MDSCs, and these cytokines, in the presence of tumor antigen-stimulated T cells, increase MDSC-induced development of immunosuppressive Tregs [142]. Additionally, prolonged IFN $\gamma$ signaling drives the expression of immunosuppressive molecules includ- 
ing TGF- $\beta$, IL-10, and IDO in MDSCs, leading to reduced T cell activity [143]. However, there is evidence to suggest that IFN $\gamma$ decreases the survival and function of granulocytic MDSCs [144]. Thus, IFN $\gamma$ is capable of positively or negatively regulating MDSC suppressive functions (Figure 2).

\subsection{Neutrophils}

Both protumor and anti-tumor roles for neutrophils have been identified and IFNIs play an important part in regulating these functions [145-149]. Andzinski et al. have shown that IFNI therapy, both in mice and humans, promotes polarization of tumorassociated neutrophils (TANs) towards an anti-tumor N1 phenotype [145]. Another recent study demonstrated that $\beta$-glucan, an agonist of trained immunity, epigenetically rewires neutrophils into an anti-tumor phenotype in an IFNI signaling-dependent manner [146]. Furthermore, IFN $\beta$ downregulates the expression of CXCR2 ligands on the surface of TANs, reducing their recruitment into tumors and inhibiting tumor angiogenesis [147]. IFN $\beta$ also induces apoptosis of TANs, limiting their lifespan in the TME [148]. Interestingly, accumulation of neutrophils in distant tissue is thought to mediate the formation of premetastatic niches. IFNb1-/ - mice have increased accumulation of neutrophils in the lungs and a higher rate of metastatic disease, suggesting that IFNI activity reduces metastatic potential through decreasing migration of neutrophils to would-be sites of metastasis [149]. These studies support the hypothesis that IFNIs can support an antitumor immune response by exerting anti-tumor effects on TANs (Figure 1).

\subsection{0. $\gamma \delta$ T Cells}

$\gamma \delta \mathrm{T}$ cells are a subset of T cells that express a T-cell receptor (TCR) composed of a gamma and delta chain (instead of the $\alpha / \beta$ TCR that is more commonly expressed in other T cells) and are not MHC restricted [150]. $\gamma \delta \mathrm{T}$ cells express T-bet and eomesodermin constitutively and so can rapidly differentiate and secrete IFN $\gamma$ once stimulated with IL-2 and IL-15, promoting anti-tumor immune responses [150]. $\gamma \delta \mathrm{T}$ cells are also capable of acting as antigen presenting cells and can activate CD8+ and CD4+ Th1 cells [151]. Finally, the majority of $\gamma \delta$ T cells can directly kill tumor cells through granzyme and perforin secretion or indirectly through IFN $\gamma$ and TNF production [151]. Loss of IFN $\gamma$ production by $\gamma \delta \mathrm{T}$ cells resulted in increased tumorigenesis following MCA challenge [152]. In an in vivo model where TCR $\delta$ deletion abrogated T cell-mediated immune response, the reintroduction of $\gamma \delta \mathrm{T}$ cells restored anti-tumor immune function. This effect required IFN $\gamma$ and perforin production by $\gamma \delta$ T cells and other lymphocytes [153]. However, the $\gamma \delta$ $\mathrm{T}$ cells found in settings of chronic inflammation are often pro-tumorigenic [151].

\subsection{Tumor Cells}

There is extensive evidence indicating that IFNIs act directly on premalignant and malignant cells through several mechanisms, including induction of cellular apoptosis and cell cycle arrest, to alter tumor growth and survival [47]. For example, IFNIs upregulate expression of the tumor suppressor p53, reducing cellular transformation [154]. Hematopoietic malignant cellular proliferation and survival is inhibited through IFNI-mediated activation of SIRT2/CDK9/STAT1 and ULK1 signaling $[155,156]$. Moreover, IFNIs exert an antitumor effect by upregulating NK ligands and MHC class I molecules on the tumor cell surface, increasing the immunogenicity of the tumor cells [89]. Several genotoxic anticancer therapies, such as radiation and chemotherapy, rely on the accumulation of DNA damage, DAMP production, and activation of IFNI-engaging pathways to promote an anticancer immune response [157,158]. However, activation of IFNI-associated pathways can also increase the expression of prosurvival ISGs, designated IFN-related DNA damage resistance signature (IRDS) genes, which can support tumor cell survival [159]. Moreover, in mouse mammary cancer cells, expression of an IFNAR1 mutant that is resistant to degradation did not alter the proliferation of these cells in vitro or when implanted subcutaneously in syngeneic mice but did increase tumor growth when implanted orthotopically into 
mammary glands [160]. These results highlight the importance of evaluating the role of IFN activity within a tumor's niche and are consistent with the findings that increased expression of IFNAR1 is associated with a poor prognosis in breast cancer patients [160]. Similarly, investigations into mechanisms driving the malignant phenotype of glioblastoma have identified the IFNI-regulated human Schlafen 5 (SLFN5) gene as a critical driver of malignant characteristics [161]. These studies have shown that SLFN5 interacts with STAT1 and negatively controls its transcriptional activity. Thus, IFNIs can drive direct pro- and anti-tumor effects on tumor cells (Figure 1).

IFN $\gamma$ also acts directly on tumor cells, regulating their survival and immunogenicity through multiple mechanisms [162,163]. For example, IFN $\gamma$ increases the expression of MHC class I molecules on the surface of tumor cells, enhancing their immunogenicity and, consequently, making them more vulnerable to immune-mediated cell killing [162]. In addition to increased antigenicity, IFN $\gamma$ induces tumor cell death using several direct mechanisms. IFN $\gamma$ exposure inhibits tumor growth through upregulation of p21 and p27 and activation of p53-regulated signaling, leading to cell cycle arrest and apoptosis $[109,164]$. Moreover, IFN $\gamma$ released by CD8+ T cells inhibits expression of SLC3A2 and SLC7A11 on tumor cells, leading to tumor ferroptosis [165]. IFN $\gamma$ exposure can also result in autophagyassociated apoptosis of tumor cells via activation of cytosolic phospholipase A2-dependent production of mitochondrial reactive oxygen species [166]. Furthermore, in an in vivo model of pancreatic cancer, IFN $\gamma$ treatment was shown to inhibit CXCL8 expression on tumor cells, reducing trafficking of suppressive CXCR2+CD68+ macrophages to the TME, restoring immune activity and response to anti-PD-1 therapy [167]. In another study, intratumoral NK-derived IFN $\gamma$ was shown to induce expression of fibronectin 1 in tumor cells, changing the tumor architecture and reducing metastases formation in vivo [168].

In contrast, in an HBV-associated hepatocellular carcinoma (HCC) model, IFN $\gamma$ produced by NK cells was found to induce STAT1-dependent expression of epithelial cell adhesion molecules, promoting the epithelial-to-mesenchymal transition of HBV surface antigen-positive hepatocytes and increasing HCC incidence in vivo [169]. In another study, $\mathrm{NK}$-derived IFN $\gamma$-induced the expression of MHC class I molecules in leukemia cells and decreased their susceptibility to NK cytotoxicity [170], while in melanoma cells loss of IFN $\gamma$ signaling components increased tumor cell sensitivity to NKs [171]. Using several mouse tumor models, IFN $\gamma$ was shown to be essential for CTL-driven development of immuneresistant cancer cell clones through increased tumor cell genetic instability [172]. In another study, loss of Elf5-FBXW7 in triple negative breast cancer cells was shown to increase IFN $\gamma$ signaling, leading to enhanced PD-L1 expression on tumor cells and accumulation of immunosuppressive neutrophils in the TME [173]. Moreover, sustained signaling through IFN-induced pathways has also been associated with resistance to immune checkpoint inhibitors (ICIs) through upregulation of PD-L1, PD-L2, CTLA-4, CIITA, IDO1, CXCL12, non-classical MHC antigens and nitric oxide production in tumor cells, which inhibit the ability of the immune system to recognize these cells [174-182]. In vivo studies of the diffusion of CD8+ T cell-derived IFN $\gamma$ suggest that even few intratumoral CD8+ T cells secrete enough IFN $\gamma$ to reach tumor cells $>800 \mu \mathrm{m}$ away [183]. This may drive ongoing immunologic control of malignant cells, including variants that have lost antigen expression. However, this gradient may also lead to the upregulation of immunosuppressive proteins, such as PD-L1 and galectin-9, on tumor cells prior to T-cell arrival and immune recognition, creating immune resistant cancer cells [183]. Together, these observations highlight the dual direct role that IFN $\gamma$ plays in malignant cells (Figure 2).

As the field of oncology has increased its focus on personalized medicine, gene signatures and gene expression profiles (GEPs) have become important tools in understanding tumor biology [184]. Analyses of several tumors within T-cell inflamed TMEs identified a GEP that included IFN $\gamma$-inducible genes and could predict response to ICI therapy in melanoma and head and neck cancers [176] On the other hand, the IRDS is associated with resistance to radiation and chemotherapy $[13,159]$. In prostate cancer, an enhanced IRDS is associated with poor overall survival, and it was found to be more prevalent in 
African-American men than in European-American men [185]. These findings were correlated with the expression of a germline variant that regulates production of IFN lambda 4, a type III IFN commonly expressed in people of African ancestry [185]. African-American breast cancer patients also exhibit an elevated IFN signature compared to patients of European ancestry [186]. Further investigations into these gene signatures and associated changes within the anti-tumor immune response will likely contribute significantly to predict patient outcomes and response/resistance to chemo- or immunotherapies.

\section{Resistance Mechanisms to Interferons}

IFN dysregulation can occur through several mechanisms including downregulation of signaling effector proteins (e.g., IFNAR, JAKs), loss or silencing of key signaling components (e.g., JAK1, STATs, IRFs), or through upregulation of negative regulators (e.g., SOCS1/3) $[187,188]$. Hypermethylation of the IFN $\gamma$ promoter in CD8+ T cells isolated from cancer patients is associated with reduced IFN $\gamma$ production following CD8+ T cell stimulation and with decreased $\mathrm{T}$ cell cytotoxicity [189]. Over time, tumor infiltrating $\mathrm{T}$ cells become less responsive to antigens, release less IFN $\gamma$, and kill fewer malignant cells. Several tumor types, including melanoma and head and neck cancers, are or become unresponsive to IFNs [190-192]. These escape mechanisms have been identified both in research models and in patient samples, suggesting they aid in the growth and survival of malignancies [161]. Moreover, TME stress factors, such as hypoxia [193], tumor-expressed inflammatory cytokines such as IL-1 [194] and tumor-derived extracellular vesicles [195], have all been shown to stimulate degradation and inactivation of IFNAR and suppress downstream signaling and induction of ISGs, blunting anti-tumor immune responses. Responses to anti-tumor treatments including chemotherapy, radiation and immunotherapy rely on IFN signaling and IFN-mediated immune responses $[17,105,188]$. Therefore, it is not surprising that loss of IFN signaling within the malignant and immune cells in the TME is associated with resistance to cancer treatments. Downregulation of IFNAR is found during tumor development in melanoma patients and expression of a non-degradable IFNAR1 mutant in mice was shown to delay the formation and progression of melanoma and increase responsiveness to BRAF or PD-1 inhibitors in vivo [196]. Further studies have also shown that loss of function mutations in the IFNR and alterations in the IFN signaling pathways allow immune escape from ICIs [36,197]. More specifically, loss of function mutations in JAK1/2, decreased phosphorylation of STAT1 and truncating mutations in the $\beta 2$-microglobulin gene have all been identified in patients that develop resistance to ICIs $[198,199]$. Additionally, an acidic TME has been associated with decreased IFN $\gamma$ production by NKs and enhanced tumor growth, suggesting that the TME is often not optimized to support IFN $\gamma$-mediated immune activity [200].

\section{Conclusions}

IFNs are essential components of immune cell activation and function, allowing elimination of malignant cells. However, due to feedback mechanisms developed to prevent over-inflammation and deleterious tissue destruction, IFN-activated signals can also suppress immune activity, possibly allowing tumor growth and escape from immunosurveillance $[4,5,7,8]$. These divergent responses depend on signaling duration, tumor characteristics, and the presence of other cytokines and immune cells within the TME. As research into potential therapeutic targets of components of IFN signaling and the immune response progresses, it will be important to take into account this dual function.

Author Contributions: S.E.F., D.S., and L.C.P. contributed to the conceptualization, research, information synthesis, writing and editing of this manuscript. All authors have read and agreed to the published version of the manuscript.

Funding: The research of L.C.P. is supported by grants R01-CA77816, R01-CA121102, and I01CX000916. The research of D.S. is supported by grant R21-CA245447.

Conflicts of Interest: The authors declare no conflict of interest. 


\section{References}

1. Candeias, S.M.; Gaipl, U.S. The Immune System in Cancer Prevention, Development and Therapy. Anticancer Agents Med. Chem. 2016, 16, 101-107. [CrossRef]

2. Galluzzi, L.; Humeau, J.; Buqué, A.; Zitvogel, L.; Kroemer, G. Immunostimulation with chemotherapy in the era of immune checkpoint inhibitors. Nat. Rev. Clin. Oncol. 2020, 17, 725-741. [CrossRef]

3. Dunn, G.P.; Bruce, T.A.; Ikeda, H.; Old, L.J.; Schreiber, R.D. Cancer immunoediting: From immunosurveillance to tumor escape. Nat. Immunol. 2002, 3, 991-998. [CrossRef] [PubMed]

4. Dunn, G.P.; Koebel, C.M.; Schreiber, R.D. Interferons, immunity and cancer immunoediting. Nat. Rev. Immunol. 2006, 6, 836-848. [CrossRef] [PubMed]

5. Dunn, G.P.; Bruce, A.T.; Sheehan, K.C.F.; Shankaran, V.; Uppaluri, R.; Bui, J.D.; Diamond, M.S.; Koebel, C.M.; Arthur, C.; White, J.M.; et al. A critical function for type I interferons in cancer immunoediting. Nat. Immunol. 2005, 6, 722-729. [CrossRef] [PubMed]

6. Ivashkiv, L.B.; Donlin, L.T. Regulation of type I interferon responses. Nat. Rev. Immunol. 2014, 14, 36-49. [CrossRef] [PubMed]

7. Kursunel, M.A.; Esendagli, G. The untold story of IFN-gamma in cancer biology. Cytokine Growth Factor Rev. $2016,31,73-81$. [CrossRef] [PubMed]

8. Arimoto, K.I.; Miyauchi, S.; Stoner, S.A.; Fan, J.B.; Zhang, D.E. Negative regulation of type I IFN signaling. J. Leukoc. Biol. 2018, 103, 1099-1116. [CrossRef] [PubMed]

9. Saleiro, D.; Platanias, L.C. Interferon signaling in cancer. Non-canonical pathways and control of intracellular immune checkpoints. Semin. Immunol. 2019, 43, 101299. [CrossRef]

10. Platanias, L.C. Mechanisms of type-I- and type-II-interferon-mediated signaling. Nat. Rev. Immunol. 2005, 5, 375-386. [CrossRef]

11. De Weerd, N.A.; Nguyen, T. The interferons and their receptors-Distribution and regulation. Immunol. Cell Biol. 2012, 90, 483-491. [CrossRef]

12. Der, S.D.; Zhou, A.; Williams, B.R.; Silverman, R.H. Identification of genes differentially regulated by interferon $\alpha, \beta$, or $\gamma$ using oligonucleotide arrays. Proc. Natl. Acad. Sci. USA 1998, 95, 15623-15628. [CrossRef] [PubMed]

13. Cheon, H.; Borden, E.C.; Stark, G.R. Interferons and their stimulated genes in the tumor microenvironment. Semin. Oncol. 2014, 41, 156-173. [CrossRef] [PubMed]

14. Pestka, S.; Langer, J.A.; Zoon, K.C.; Samuel, C.E. Interferons and their actions. Annu. Rev. Biochem. 1987, 56, 727-777. [CrossRef] [PubMed]

15. Pestka, S. The human interferon $\alpha$ species and hybrid proteins. Semin. Oncol. 1997, 24, S9-4-S9-17.

16. Pestka, S.; Krause, C.D.; Walter, M.R. Interferons, interferon-like cytokines, and their receptors. Immunol. Rev. 2004, $202,8-32$. [CrossRef]

17. Zitvogel, L.; Galluzzi, L.; Kepp, O.; Smyth, M.J.; Droemer, G. Type I interferons in anticancer immunity. Nat. Rev. Immunol. 2015, 15, 405-414. [CrossRef]

18. Fuertes, M.B.; Woo, S.R.; Burnett, B.; Fu, Y.X.; Gajewski, T.F. Type I interferon response and innate immune sensing of cancer. Trends Immunol. 2013, 34, 67-73. [CrossRef]

19. $\mathrm{Wu}, \mathrm{J} . ;$ Chen, Z.J. Innate immune sensing and signaling of cytosolic nucleic acids. Annu. Rev. Immunol. 2014, 32, 461-488. [CrossRef]

20. Khoo, L.T.; Chen, L.Y. Role of the cGAS-STING pathway in cancer development and oncotherapeutic approaches. EMBO Rep. 2018, 19, e46935. [CrossRef]

21. Woo, S.R.; Fuertes, M.B.; Corrales, L.; Spranger, S.; Furdyna, M.J.; Leung, M.Y.K.; Duggan, R.; Wang, Y.; Barber, G.N.; Fitzgerald, K.A.; et al. STING-dependent cytosolic DNA sensing mediates innate immune recognition of immunogenic tumors. Immunity 2014, 41, 830-842. [CrossRef]

22. Chen, Q.; Sun, L.; Chen, Z.J. Regulation and function of the cGAS-STING pathway of cytosolic DNA sensing. Nat. Immunol. 2016, 17, 1142-1149. [CrossRef]

23. Mazewski, C.; Perez, R.E.; Fish, E.N.; Platanias, L.C. Type I Interferon (IFN)-Regulated Activation of Canonical and Non-Canonical Signaling Pathways. Front. Immunol. 2020, 11, 606456. [CrossRef]

24. Fish, E.N.; Platanias, L.C. Interferon receptor signaling in malignancy: A network of cellular pathways defining biological outcomes. Mol. Cancer Res. 2014, 12, 1691-1703. [CrossRef]

25. Bernabei, P.; Coccia, E.M.; Rigamonti, L.; Bosticardo, M.; Forni, G.; Pestka, S.; Krause, C.D.; Battisttini, A.; Novelli, F. Interferongamma receptor 2 expression as the deciding factor in human T, B, and myeloid cell proliferation or death. J. Leukoc. Biol. 2001, 70, 950-960. [PubMed]

26. Gough, D.J.; Levy, D.E.; Johnstone, R.W.; Clarke, C.J. IFNgamma signaling-does it mean JAK-STAT? Cytokine Growth Factor Rev. 2008, 19, 383-394. [CrossRef]

27. Macri, C.; Pang, E.S.; Patton, T.; O'Keeffe, M. Dendritic cell subsets. Semin. Cell Dev. Biol. 2018, 84, 11-21. [CrossRef]

28. Montoya, M.; Schiavoni, G.; Mattei, F.; Gresser, I.; Belardelli, F.; Borrow, P.; Tough, D.F. Type I interferons produced by dendritic cells promote their phenotypic and functional activation. Blood 2002, 99, 3263-3271. [CrossRef]

29. Medrano, R.F.V.; Hunger, A.; Mendonca, S.A.; Barbuto, J.A.M.; Strauss, B.E. Immunomodulatory and antitumor effects of type I interferons and their application in cancer therapy. Oncotarget 2017, 8, 71249-71284. [CrossRef] [PubMed] 
30. Santini, S.M.; Lapenta, C.; Logozzi, M.; Parlato, S.; Spada, M.; Di Pucchio, T.; Belardelli, F. Type I interferon as a powerful adjuvant for monocyte-derived dendritic cell development and activity in vitro and in Hu-PBL-SCID mice. J. Exp. Med. 2000, 191, 1777-1788. [CrossRef] [PubMed]

31. Schiavoni, G.; Mattei, F.; Gabriele, L. Type I Interferons as Stimulators of DC-Mediated Cross-Priming: Impact on Anti-Tumor Response. Front. Immunol. 2013, 4, 483. [CrossRef] [PubMed]

32. Lattanzi, L.; Rozera, C.; Marescotti, D.; D’Agostino, G.; Santodonato, L.; Cellini, S.; Belardelli, F.; Gavioli, R.; Ferrantini, M. IFN-alpha boosts epitope cross-presentation by dendritic cells via modulation of proteasome activity. Immunobiology 2011, 216, 537-547. [CrossRef] [PubMed]

33. Spadaro, F.; Lapenta, C.; Donati, S.; Abalsamo, L.; Barnaba, V.; Belardelli, F.; Santini, S.M.; Ferrantini, M. IFN-alpha enhances cross-presentation in human dendritic cells by modulating antigen survival, endocytic routing, and processing. Blood 2012, 119, 1407-1417. [CrossRef]

34. Parlato, S.; Santini, S.M.; Lapenta, C.; Di Pucchio, T.; Logozzi, M.; Spada, M.; Giammarioli, A.M.; Malorni, W.; Fais, S.; Belardelli, F. Expression of CCR-7, MIP-3beta, and Th-1 chemokines in type I IFN-induced monocyte-derived dendritic cells: Importance for the rapid acquisition of potent migratory and functional activities. Blood 2001, 98, 3022-3029. [CrossRef] [PubMed]

35. Longhi, M.P.; Trumpfheller, C.; Idoyaga, J.; Caskey, M.; Matos, I.; Kluger, C.; Salazar, A.M.; Colonna, M.; Steinman, R.M. Dendritic cells require a systemic type I interferon response to mature and induce CD4+ Th1 immunity with poly IC as adjuvant. J. Exp. Med. 2009, 206, 1589-1602. [CrossRef]

36. Arico, E.; Castiello, L.; Capone, I.; Gabriele, L.; Belardelli, F. Type I interferons and cancer: An evolving story demanding novel clinical applications. Cancers 2019, 11, 1943. [CrossRef] [PubMed]

37. Mattei, F.; Schiavoni, G.; Belardelli, F.; Tough, D.F. IL-15 is expressed by dendritic cells in response to type I IFN, double-stranded RNA, or lipopolysaccharide and promotes dendritic cell activation. J. Immunol. 2001, 167, 1179-1187. [CrossRef] [PubMed]

38. McKenna, K.; Beignon, A.S.; Bhardwaj, N. Plasmacytoid dendritic cells: Linking innate and adaptive immunity. J. Virol. 2005, 79, 17-27. [CrossRef]

39. Dai, J.H.; Megjugorac, N.J.; Amrute, S.B.; Fitzgerald-Bocarsly, P. Regulation of IFN regulatory factor-7 and IFN-alpha production by enveloped virus and lipopolysaccharide in human plasmacytoid dendritic cells. J. Immunol. 2004, 173, 1535-1548. [CrossRef]

40. Le Mercier, I.; Poujol, D.; Sanlaville, A.; Sisirak, V.; Gobert, M.; Durand, I.; Dubois, B.; Treilleux, I.; Marvel, J.; Vlach, J.; et al. Tumor promotion by intratumoral plasmacytoid dendritic cells is reversed by TLR7 ligand treatment. Cancer Res. 2013, 73, 4629-4640. [CrossRef] [PubMed]

41. Veglia, F.; Gabrilovich, D.I. Dendritic cells in cancer: The role revisited. Curr. Opin. Immunol. 2017, 45, 43-51. [CrossRef] [PubMed]

42. Sisirak, V.; Faget, J.; Gobert, M.; Goutagny, N.; Vey, N.; Treilleux, I.; Renaudineau, S.; Poyet, G.; Labidi-Galy, S.I.; Goddard-Leon, S.; et al. Impaired IFN- $\alpha$ production by plasmacytoid dendritic cells favors regulatory T-cell expansion that may contribute to breast cancer progression. Cancer Res. 2012, 72, 5188-5197. [CrossRef]

43. Garris, C.S.; Arlauckas, S.P.; Kohler, R.H.; Trefny, M.P.; Garren, S.; Piot, C.; Engblom, C.; Pfirschke, C.; Siwicki, M.; Gungabeesoon, J.; et al. Successful Anti-PD-1 Cancer Immunotherapy Requires T Cell-Dendritic Cell Crosstalk Involving the Cytokines IFN- $\gamma$ and IL-12. Immunity 2018, 49, 1148-1161.e7. [CrossRef] [PubMed]

44. Lövgren, T.; Sarhan, D.; Truxová, I.; Choudhary, B.; Maas, R.; Melief, J.; Nyström, M.; Edbäck, U.; Vermeij, R.; Scurti, G.; et al. Enhanced stimulation of human tumor-specific T cells by dendritic cells matured in the presence of interferon- $\gamma$ and multiple toll-like receptor agonists. Cancer Immunol. Immunother. 2017, 66, 1333-1344. [CrossRef]

45. Alspach, E.; Lussier, D.M.; Schrieber, R.D. Interferon gamma and its important roles in promoting and inhibiting spontaneous and therapeutic cancer immunity. Cold Spring Harb. Perspect. Biol. 2019, 11, a028480. [CrossRef] [PubMed]

46. Sheng, K.C.; Day, S.; Wright, M.D.; Stojanovska, L.; Apostolopoulos, V. Enhanced dendritic cell-mediated antigen-specific CD4+ T cell responses: IFN-gamma aids TLR stimulation. J. Drug Deliv. 2013, 2013, 516749. [CrossRef] [PubMed]

47. Sprooten, J.; Agostinis, P.; Garg, A.D. Type I interferons and dendritic cells in cancer immunotherapy. Int. Rev. Cell Mol. Biol. 2019, 348, 217-262. [PubMed]

48. Hervas-Stubbs, S.; Perez-Gracia, J.L.; Rouzaut, A.; Sanmamed, M.F.; Le Bon, A.; Melero, I. Direct effects of type I interferons on cells of the immune system. Clin. Cancer Res. 2011, 17, 2619-2627. [CrossRef]

49. Schreiner, B.; Mitsdoerffer, M.; Kieseier, B.C.; Chen, L.; Hartung, H.P.; Weller, M.; Wiendl, H. Interferon-beta enhances monocyte and dendritic cell expression of B7-H1 (PD-L1), a strong inhibitor of autologous T-cell activation: Relevance for the immune modulatory effect in multiple sclerosis. J. Neuroimmunol. 2004, 155, 172-182. [CrossRef]

50. Snell, L.M.; McGaha, T.L.; Brooks, D.G. Type I Interferon in Chronic Virus Infection and Cancer. Trends Immunol. 2017, 38, 542-557. [CrossRef]

51. Nirschl, C.J.; Suarez-Farinas, M.; Izar, B.; Prakadan, S.; Dannenfelser, R.; Tirosh, I.; Liu, Y.; Zhu, Q.; Devi, K.S.P.; Carroll, S.L.; et al. IFN $\gamma$-Dependent Tissue-Immune Homeostasis Is Co-opted in the Tumor Microenvironment. Cell 2017, 170, 127-141.e115. [CrossRef]

52. Jurgens, B.; Hainz, U.; Fuchs, D.; Felzmann, T.; Heitger, A. Interferon- $\gamma$-triggered indoleamine 2,3-dioxygenase competence in human monocyte-derived dendritic cells induces regulatory activity in allogeneic T cells. Blood 2009, 114, 3235-3243. [CrossRef]

53. Noh, K.T.; Son, K.H.; Jung, I.D.; Kang, T.H.; Choi, C.H.; Park, Y.M. Glycogen Synthase Kinase-3 $\beta$ (GSK-3 $\beta$ ) Inhibition Enhances Dendritic Cell-based Cancer Vaccine Potency via Suppression of Interferon- $\gamma$-induced Indoleamine 2,3-Dioxygenase Expression. J. Biol. Chem. 2015, 290, 12394-12402. [CrossRef] [PubMed] 
54. Sabado, R.L.; Balan, S.; Bhardwaj, N. Dendritic cell-based immunotherapy. Cell Res. 2017, 27, 74-95. [CrossRef]

55. Bialek-Waldmann, J.K.; Heuser, M.; Ganser, A.; Stripecke, R. Monocytes reprogrammed with lentiviral vectors co-expressing GM-CSF, IFN- $\alpha 2$ and antigens for personalized immune therapy of acute leukemia pre- or post-stem cell transplantation. Cancer Immunol. Immunother. 2019, 68, 1891-1899. [CrossRef] [PubMed]

56. Zanker, D.J.; Spurling, A.J.; Brockwell, N.K.; Owen, K.L.; Zakhour, J.M.; Robinson, T.; Duivenvoorden, H.M.; Hertzog, P.J.; Mullins, S.R.; Wilkinson, R.W.; et al. Intratumoral administration of the Toll-like receptor 7/8 agonist 3M-052 enhances interferon-driven tumor immunogenicity and suppresses metastatic spread in preclinical triple-negative breast cancer. Clin. Transl. Immunol. 2020, 9, e1177. [CrossRef]

57. Graham, J.P.; Authie, P.; Palucka, A.K.; Zurawski, G. Targeting interferon-alpha to dendritic cells enhances a CD8+ T cell response to a human CD40-targeted cancer vaccine. Vaccine 2017, 35 Pt B, 4532-4539. [CrossRef]

58. Sköld, A.E.; Mathan, T.S.M.; van Beek, J.J.P.; Flórez-Grau, G.; van den Beukel, M.D.; Sittig, S.P.; Wimmers, F.; Bakdash, G.; Schreibelt, G.; de Vries, I.J.M. Naturally produced type I IFNs enhance human myeloid dendritic cell maturation and IL-12p70 production and mediate elevated effector functions in innate and adaptive immune cells. Cancer Immunol. Immunother. 2018, 67, 1425-1436. [CrossRef]

59. Gordy, J.T.; Luo, K.; Kapoor, A.; Kim, E.S.; Ayeh, S.K.; Karakousis, P.C.; Markham, R.B. Treatment with an immature dendritic cell-targeting vaccine supplemented with IFN- $\alpha$ and an inhibitor of DNA methylation markedly enhances survival in a murine melanoma model. Cancer Immunol. Immunother. 2020, 69, 569-580. [CrossRef]

60. Sheng, L.; Chen, X.; Wang, Q.; Lyu, S.; Li, P. Interferon- $\alpha 2 b$ enhances survival and modulates transcriptional profiles and the immune response in melanoma patients treated with dendritic cell vaccines. Biomed. Pharmacother. 2020, 125, 109966. [CrossRef] [PubMed]

61. Le Naour, J.; Zitvogel, L.; Galluzzi, L.; Vacchelli, E.; Kroemer, G. Trial watch: STING agonists in cancer therapy. Oncoimmunology 2020, 9, 1777624. [CrossRef]

62. Zhu, Y.; An, X.; Zhang, X.; Qiao, Y.; Zheng, T.; Li, X. STING: A master regulator in the cancer-immunity cycle. Mol. Cancer 2019, 18, 152. [CrossRef]

63. Shapouri-Moghaddam, A.; Mohammadian, S.; Vazini, H.; Taghadosi, M.; Esmaeili, S.A.; Mardani, F.; Seifi, B.; Mohammadi, A.; Afshari, J.T.; Sahebkar, A. Macrophage plasticity, polarization, and function in health and disease. J. Cell Physiol. 2018, 233, 6425-6440. [CrossRef]

64. Parker, B.S.; Rautela, J.; Hertzog, P.J. Antitumour actions of interferons: Implications for cancer therapy. Nat. Rev. Cancer 2016, 16, 131-144. [CrossRef]

65. Müller, E.; Speth, M.; Christopoulos, P.F.; Lunde, A.; Avdagic, A.; Øynebråten, I.; Corthay, A. Both Type I and Type II Interferons Can Activate Antitumor M1 Macrophages When Combined with TLR Stimulation. Front. Immunol. 2018, 9, 2520. [CrossRef] [PubMed]

66. Hu, X.; Chakravarty, S.D.; Ivashkiv, L.B. Regulation of interferon and Toll-like receptor signaling during macrophage activation by opposing feedforward and feedback inhibition mechanisms. Immunol. Rev. 2008, 226, 41-56. [CrossRef] [PubMed]

67. Jeong, S.K.; Yang, K.; Park, Y.S.; Choi, Y.J.; Oh, S.J.; Lee, C.W.; Lee, K.Y.; Jeong, M.H.; Jo, W.S. Interferon gamma induced by resveratrol analog, HS-1793, reverses the properties of tumor associated macrophages. Int. Immunopharmacol. 2014, 22, 303-310. [CrossRef] [PubMed]

68. Su, X.; Yu, Y.; Zhong, Y.; Giannopoulou, E.G.; Hu, X.; Liu, H.; Cross, J.R.; Rätsch, G.; Rice, C.M.; Ivashkiv, L.B. Interferon- $\gamma$ regulates cellular metabolism and mRNA translation to potentiate macrophage activation. Nat. Immunol. 2015, 16, 838-849. [CrossRef]

69. Trost, M.; English, L.; Lemieux, S.; Courcelles, M.; Desjardins, M.; Thibault, P. The phagosomal proteome in interferon-gammaactivated macrophages. Immunity 2009, 30, 143-154. [CrossRef]

70. Siveen, K.S.; Kuttan, G. Role of macrophages in tumour progression. Immunol. Lett. 2009, 123, 97-102. [CrossRef]

71. Escobar, G.; Moi, D.; Ranghetti, A.; Ozkal-Baydin, P.; Squadrito, M.L.; Kajaste-Rudnitski, A.; Bondanza, A.; Gentner, B.; De Palma, M.; Mazzieri, R.; et al. Genetic engineering of hematopoiesis for targeted IFN-alpha delivery inhibits breast cancer progression. Sci. Transl. Med. 2014, 6, 217ra3. [CrossRef] [PubMed]

72. Salvagno, C.; Ciampricotti, M.; Tuit, S.; Hau, C.S.; van Weverwijk, A.; Coffelt, S.B.; Kersten, K.; Vrijland, K.; Kos, K.; Ulas, T.; et al. Therapeutic targeting of macrophages enhances chemotherapy efficacy by unleashing type I interferon response. Nat. Cell Biol. 2019, 21, 511-521. [CrossRef] [PubMed]

73. Willingham, S.B.; Volkmer, J.P.; Gentles, A.J.; Sahoo, D.; Dalerba, P.; Mitra, S.S.; Wang, J.; Contreras-Trujillo, H.; Martin, R.; Cohen, J.D.; et al. The CD47-signal regulatory protein alpha (SIRPa) interaction is a therapeutic target for human solid tumors. Proc. Natl. Acad. Sci. USA 2012, 109, 6662-6667. [CrossRef] [PubMed]

74. Chao, M.P.; Weissman, I.L.; Majeti, R. The CD47-SIRPalpha pathway in cancer immune evasion and potential therapeutic implications. Curr. Opin. Immunol. 2012, 24, 225-232. [CrossRef] [PubMed]

75. De Silva, S.; Fromm, G.; Shuptrine, C.W.; Johannes, K.; Patel, A.; Yoo, K.J.; Huang, K.; Schreiber, T.H. CD40 Enhances Type I Interferon Responses Downstream of CD47 Blockade, Bridging Innate and Adaptive Immunity. Cancer Immunol. Res. 2020, 8 , 230-245. [CrossRef] [PubMed]

76. Haabeth, O.A.; Lorvik, K.B.; Hammarström, C.; Donaldson, I.M.; Haraldsen, G.; Bogen, B.; Corthay, A. Inflammation driven by tumour-specific Th1 cells protects against B-cell cancer. Nat. Commun. 2011, 2, 240. [CrossRef] 
77. Spear, P.; Barber, A.; Rynda-Apple, A.; Sentman, C.L. Chimeric antigen receptor T cells shape myeloid cell function within the tumor microenvironment through IFN-gamma and GM-CSF. J. Immunol. 2012, 188, 6389-6398. [CrossRef]

78. Muller, L.; Aigner, P.; Stoiber, D. Type I interferons and natural killer cell regulation in cancer. Front. Immunol. 2017, 8, 304. [CrossRef]

79. Stetson, D.B.; Mohrs, M.; Reinhardt, R.L.; Baron, J.L.; Wang, Z.E.; Gapin, L.; Kronenberg, M.; Locksley, R.M. Constitutive cytokine mRNAs mark natural killer (NK) and NK T cells poised for rapid effector function. J. Exp. Med. 2003, 198, 1069-1076. [CrossRef]

80. Nguyen, K.B.; Salazar-Mather, T.P.; Dalod, M.Y.; Van Deusen, J.B.; Wei, X.Q.; Liew, F.Y.; Caligiuri, M.A.; Durbin, J.E.; Biron, C.A. Coordinated and distinct roles for IFN-alpha beta, IL-12, and IL-15 regulation of NK cell responses to viral infection. J. Immunol. 2002, 169, 4279-4287. [CrossRef]

81. Degli-Esposti, M.A.; Smyth, M.J. Close encounters of different kinds: Dendritic cells and NK cells take centre stage. Nat. Rev. Immunol. 2005, 5, 112-124. [CrossRef]

82. Takashima, K.; Takeda, Y.; Oshiumi, H.; Shime, H.; Okabe, M.; Ikawa, M.; Matsumoto, M.; Seya, T. STING in tumor and host cells cooperatively work for NK cell-mediated tumor growth retardation. Biochem. Biophys. Res. Commun. 2016, 478, 1764-1771. [CrossRef]

83. Nicolai, C.J.; Wolf, N.; Chang, I.C.; Kirn, G.; Marcus, A.; Ndubaku, C.O.; McWhirter, S.M.; Raulet, D.H. NK cells mediate clearance of CD8+ T cell-resistant tumors in response to STING agonists. Sci. Immunol. 2020, 5, eaaz2738. [CrossRef]

84. Zanker, D.J.; Owen, K.L.; Baschuk, N.; Spurling, A.J.; Parker, B.S. Loss of type I IFN responsiveness impairs natural killer cell antitumor activity in breast cancer. Cancer Immunol. Immunother. 2021. online ahead of print. [CrossRef]

85. Zhao, Y.; Chen, W.; Zhu, W.; Meng, H.; Chen, J.; Zhang, J. Overexpression of interferon regulatory factor 7 (IRF7) reduces bone metastasis of prostate cancer cells in mice. Oncol. Res. 2017, 25, 511-522. [CrossRef]

86. Swann, J.B.; Hayakawa, Y.; Zerafa, N.; Sheehan, K.C.; Scott, B.; Schreiber, R.D.; Hertzog, P.; Smyth, M.J. Type I IFN contributes to NK cell homeostasis, activation, and antitumor function. J. Immunol. 2007, 178, 7540-7549. [CrossRef]

87. Rautela, J.; Baschuk, N.; Slaney, C.Y.; Jayatilleke, K.M.; Xiao, K.; Bidwell, B.N.; Lucas, E.C.; Hawkins, E.D.; Lock, P.; Wong, C.S.; et al. Loss of host type-I IFN signaling accelerates metastasis and impairs NK-cell antitumor function in multiple models of breast cancer. Cancer Immunol. Res. 2015, 3, 1207-1217. [CrossRef] [PubMed]

88. Bidwell, B.N.; Slaney, C.Y.; Withana, N.P.; Forster, S.; Cao, Y.; Loi, S.; Andrews, D.; Mikeska, T.; Mangan, N.E.; Samarajiwa, S.A.; et al. Silencing of IRF7 pathways in breast cancer cells promotes bone metastasis through immune escape. Nat. Med. 2012, 18, 1224-1231. [CrossRef] [PubMed]

89. Oh, H.; Kim, M.H.; Choi, S.J.; Ban, Y.H.; Lee, H.K.; Shin, E.C.; Lee, K.M.; Ha, S.J. Sustained type I interferon reinforces NK cell-mediated cancer immunosurveillance during chronic virus infection. Cancer Immunol. Res. 2019, 7, 584-599. [CrossRef] [PubMed]

90. Wendel, M.; Galani, I.E.; Sur-Payer, E.; Cerwenka, A. Natural killer cell accumulation in tumors is dependent on IFN-gamma and CXCR3 ligands. Cancer Res. 2008, 68, 8437-8445. [CrossRef] [PubMed]

91. Bellucci, R.; Martin, A.; Bommarito, D.; Wang, K.; Hansen, S.H.; Freeman, G.J.; Ritz, J. Interferon- $\gamma$-induced activation of JAK1 and JAK2 suppresses tumor cell susceptibility to NK cells through upregulation of PD-L1 expression. Oncoimmunology 2015, 4, e1008824. [CrossRef] [PubMed]

92. Aquino-Lopez, A.; Senyukov, V.V.; Vlasic, Z.; Kleinerman, E.S.; Lee, D.A. Interferon gamma induces changes in natural killer (NK) cell ligand expression and alters NK cell-mediated lysis of pediatric cancer cell lines. Front. Immunol. 2017, 8, 391. [CrossRef] [PubMed]

93. Luckheeram, R.V.; Zhou, R.; Verma, A.D.; Xia, B. CD4 $4^{+}$cells: Differentiation and functions. Clin. Dev. Immunol. 2012, 2012, 925135. [CrossRef]

94. Brinkmann, V.; Geiger, T.; Alkan, S.; Heusser, C.H. Interferon alpha increases the frequency of interferon gamma-producing human CD4+ T cells. J. Exp. Med. 1993, 178, 1655-1663. [CrossRef]

95. Schulz, E.G.; Mariani, L.; Radbruch, A.; Hofer, T. Sequential polarization and imprinting of type 1 T helper lymphocytes by interferon-gamma and interleukin-12. Immunity 2009, 30, 673-683. [CrossRef]

96. Dagenais-Lussier, X.; Loucif, H.; Murira, A.; Laulhé, X.; Stäger, S.; Lamarre, A.; van Grevenynghe, J. Sustained IFN-I Expression during Established Persistent Viral Infection: A “Bad Seed" for Protective Immunity. Viruses 2017, 10, 12. [CrossRef]

97. Zhang, N.; Bevan, M.J. CD8+ T cells: Foot soldiers of the immune system. Immunity 2011, 35, 161-168. [CrossRef]

98. Agarwal, P.; Raghavan, A.; Nandiwada, S.L.; Curtsinger, J.M.; Bohjanen, P.R.; Mueller, D.L.; Mescher, M.F. Gene regulation and chromatin remodeling by IL-12 and type I IFN in programming for CD8 T cell effector function and memory. J. Immunol. 2009, 183, 1695-1704. [CrossRef] [PubMed]

99. Fuertes, M.B.; Kacha, A.K.; Kline, J.; Woo, S.R.; Kranz, D.M.; Murphy, K.M.; Gajewski, T.F. Host type I IFN signals are required for antitumor CD8+ T cell responses through CD8 $\alpha+$ dendritic cells. J. Exp. Med. 2011, 208, 2005-2016. [CrossRef]

100. Curtsinger, J.M.; Mescher, M.F. Inflammatory cytokines as a third signal for T cell activation. Curr. Opin. Immunol. 2010, 22, 333-340. [CrossRef] [PubMed]

101. Owen, K.L.; Brockwell, N.K.; Parker, B.S. JAK-STAT Signaling: A Double-Edged Sword of Immune Regulation and Cancer Progression. Cancers 2019, 11, 2002. [CrossRef]

102. Hiroishi, K.; Tüting, T.; Lotze, M.T. IFN-alpha-expressing tumor cells enhance generation and promote survival of tumor-specific CTLs. J. Immunol. 2000, 164, 567-572. [CrossRef] 
103. Katlinski, K.V.; Gui, J.; Katlinskaya, Y.V.; Ortiz, A.; Chakraborty, R.; Bhattacharya, S.; Carbone, C.J.; Beiting, D.P.; Girondo, M.A.; Peck, A.R.; et al. Inactivation of Interferon Receptor Promotes the Establishment of Immune Privileged Tumor Microenvironment. Cancer Cell 2017, 31, 194-207. [CrossRef]

104. Lu, C.; Klement, J.D.; Ibrahim, M.L.; Xiao, W.; Redd, P.S.; Nayak-Kapoor, A.; Zhou, G.; Liu, K. Type I interferon suppresses tumor growth through activating the STAT3-granzyme B pathway in tumor infiltrating cytotoxic T lymphocytes. J. Immunother. Cancer 2019, 7, 157. [CrossRef] [PubMed]

105. Wang, S.; Campos, J.; Gallotta, M.; Gong, M.; Crain, C.; Naik, E.; Coffman, R.L.; Guiducci, C. Intratumoral injection of a CpG oligonucleotide reverts resistance to PD-1 blockade by expanding multifunctional CD8+ T cells. Proc. Natl. Acad. Sci. USA 2016, 113, E7240-E7249. [CrossRef] [PubMed]

106. Sumida, T.S.; Dulberg, S.; Schupp, J.; Stillwell, H.A.; Axisa, P.P.; Comi, M.; Lincoln, M.; Unterman, A.; Kaminski, N.; Madi, A.; et al. Type I Interferon Transcriptional Network Regulates Expression of Coinhibitory Receptors in Human T cells. bioRxiv 2020. [CrossRef]

107. Zimmerman, M.; Yang, D.; Hu, X.; Liu, F.; Singh, N.; Browning, D.; Ganapathy, V.; Chandler, P.; Choubey, D.; Abrams, S.I.; et al. IFN-gamma upregulates survivin and Ifi202 expression to induce survival and proliferation of tumor-specific T cells. PLoS ONE 2010, 5, e14076. [CrossRef]

108. Castro, F.; Cardoso, A.P.; Goncalves, R.M.; Serre, K.; Oliveira, M.J. Interferon-gamma at the crossroads of tumor immune surveillance or evasion. Front. Immunol. 2018, 9, 847. [CrossRef]

109. Pai, C.S.; Huang, J.T.; Lu, X.; Simons, D.M.; Park, C.; Chang, A.; Tamaki, W.; Liu, E.; Roybal, K.T.; Seagal, J.; et al. Clonal deletion of tumor-specific T cells by interferon-gamma confers therapeutic resistance to combination immune checkpoint blockade. Immunity 2019, 50, 477-492.e478. [CrossRef]

110. Gujer, C.; Sandgren, K.J.; Douagi, I.; Adams, W.C.; Sundling, C.; Smed-Sorensen, A.; Seder, R.A.; Karlsson Hedestam, G.B.; Lore, $\mathrm{K}$. IFN-alpha produced by human plasmacytoid dendritic cells enhances T cell-dependent naive B cell differentiation. J. Leukoc. Biol. 2011, 89, 811-821. [CrossRef]

111. Braun, D.; Caramalho, I.; Demengeot, J. IFN-alpha/beta enhances BCR-dependent B cell responses. Int. Immunol. 2002, 14, 411-419. [CrossRef]

112. Le Bon, A.; Thompson, C.; Kamphuis, E.; Durand, V.; Rossmann, C.; Kalinke, U.; Tough, D.F. Cutting edge: Enhancement of antibody responses through direct stimulation of B and T cells by type I IFN. J. Immunol. 2006, 176, 2074-2078. [CrossRef]

113. Schleimann, M.H.; Kobberø, M.L.; Vibholm, L.K.; Kjær, K.; Giron, L.B.; Busman-Sahay, K.; Chan, C.N.; Nekorchuk, M.; Schmidt, M.; Wittig, B.; et al. TLR9 agonist MGN1703 enhances B cell differentiation and function in lymph nodes. EBioMedicine 2019, 45, 328-340. [CrossRef]

114. Smith, M.; García-Martínez, E.; Pitter, M.R.; Fucikova, J.; Spisek, R.; Zitvogel, L.; Kroemer, G.; Galluzzi, L. Trial Watch: Toll-like receptor agonists in cancer immunotherapy. Oncoimmunology 2018, 7, e1526250. [CrossRef] [PubMed]

115. Bao, Y.; Liu, X.; Han, C.; Xu, S.; Xie, B.; Zhang, Q.; Gu, Y.; Hou, J.; Qian, L.; Qian, C.; et al. Identification of IFN- $\gamma-$ producing innate B cells. Cell Res. 2014, 24, 161-176. [CrossRef] [PubMed]

116. Yun, S.O.; Shin, H.Y.; Kang, C.Y.; Kang, H.J. Generation of antigen-specific cytotoxic T lymphocytes with activated B cells. Cytotherapy 2017, 19, 119-127. [CrossRef]

117. Wennhold, K.; Simabukuro-Vornhagen, A.; von Bergwelt-Baildon, M. B cell-based cancer immunotherapy. Transfus. Med. Hemother. 2019, 46, 36-46. [CrossRef]

118. Togashi, Y.; Shitara, K.; Nishikawa, H. Regulatory T cells in cancer immunosuppression-Implications for anticancer therapy. Nat. Rev. Clin. Oncol. 2019, 16, 356-371. [CrossRef]

119. Pace, L.; Vitale, S.; Dettori, B.; Palombi, C.; La Sorsa, V.; Belardelli, F.; Proietti, E.; Doria, G. APC activation by IFN-alpha decreases regulatory $\mathrm{T}$ cell and enhances Th cell functions. J. Immunol. 2010, 184, 5969-5979. [CrossRef]

120. Hashimoto, H.; Ueda, R.; Narumi, K.; Heike, Y.; Yoshida, T.; Aoki, K. Type I IFN gene delivery suppresses regulatory T cells within tumors. Cancer Gene Ther. 2014, 21, 532-541. [CrossRef]

121. Hirata, A.; Hashimoto, H.; Shibasaki, C.; Narumi, K.; Aoki, K. Intratumoral IFN- $\alpha$ gene delivery reduces tumor-infiltrating regulatory T cells through the downregulation of tumor CCL17 expression. Cancer Gene Ther. 2019, 26, 334-343. [CrossRef]

122. Gangaplara, A.; Martens, C.; Dahlstrom, E.; Metidji, A.; Gokhale, A.S.; Glass, D.D.; Lopez-Ocasio, M.; Baur, R.; Kanakabandi, K.; Porcella, S.F.; et al. Type I interferon signaling attenuates regulatory $\mathrm{T}$ cell function in viral infection and in the tumor microenvironment. PLoS Pathog. 2018, 14, e1006985. [CrossRef]

123. Anz, D.; Rapp, M.; Eiber, S.; Koelzer, V.H.; Thaler, R.; Haubner, S.; Knott, M.; Nagel, S.; Golic, M.; Wiedemann, G.M.; et al. Suppression of intratumoral CCL22 by type I interferon inhibits migration of regulatory $\mathrm{T}$ cells and blocks cancer progression. Cancer Res. 2015, 75, 4483-4493. [CrossRef] [PubMed]

124. Lee, S.E.; Li, X.; Kim, J.C.K.; Lee, J.; González-Navajas, J.M.; Hong, S.H.; Park, I.K.; Rhee, J.H.; Raz, E. Type I interferons maintain Foxp3 expression and T-regulatory cell functions under inflammatory conditions in mice. Gastroenterology 2012, 143, 145-154. [CrossRef] [PubMed]

125. Metidji, A.; Rieder, S.A.; Glass, D.D.; Cremer, I.; Punkosdy, G.A.; Shevach, E.M. IFN- $\alpha$ / $\beta$ receptor signaling promotes regulatory $\mathrm{T}$ cell development and function under stress conditions. J. Immunol. 2015, 194, 4265-4276. [CrossRef] 
126. Overacre-Delgoffe, A.E.; Chikina, M.; Dadey, R.E.; Yano, H.; Brunazzi, E.A.; Shayan, G.; Horne, W.; Moskovitz, J.M.; Kolls, J.K.; Sander, C.; et al. Interferon-gamma drives Treg fragility to promote anti-tumor immunity. Cell 2017, 169, 1130-1141.e1111. [CrossRef] [PubMed]

127. Cao, X.; Leonard, K.; Collins, L.I.; Cai, S.F.; Mayer, J.C.; Payton, J.E.; Walter, M.J.; Piwnica-Worms, D.; Schreiber, R.D.; Ley, T.J. Interleukin 12 stimulates IFN-gamma-mediated inhibition of tumor-induced regulatory T-cell proliferation and enhances tumor clearance. Cancer Res. 2009, 69, 8700-8709. [CrossRef] [PubMed]

128. Nishikawa, H.; Kato, T.; Tawara, I.; Ikeda, H.; Kuribayashi, K.; Allen, P.M.; Schreiber, R.D.; Old, L.J.; Shiku, H. IFN- $\gamma$ controls the generation/activation of CD4+CD25+ regulatory T cells in antitumor immune response. J. Immunol. 2005, 175, 4433-4440. [CrossRef] [PubMed]

129. Zou, Q.; Jin, J.; Xiao, Y.; Zhou, X.; Hu, H.; Cheng, X.; Kazimi, N.; Ullrich, S.E.; Sun, S.C. T Cell Intrinsic USP15 deficiency promotes excessive IFN-gamma production and an immunosuppressive tumor microenvironment in MCA-induced fibrosarcoma. Cell Rep. 2015, 13, 2470-2479. [CrossRef]

130. Ohue, Y.; Nishikawa, H. Regulatory T (Treg) cells in cancer: Can Treg cells be a new therapeutic target? Cancer Sci. 2019, 110, 2080-2089. [CrossRef]

131. Wang, D.; Quiros, J.; Mahuron, K.; Pai, C.C.; Ranzani, V.; Young, A.; Silveria, S.; Harwin, T.; Abnousian, A.; Pagani, M.; et al. Targeting EZH2 Reprograms Intratumoral Regulatory T Cells to Enhance Cancer Immunity. Cell Rep. 2018, 23, 3262-3274. [CrossRef]

132. Mundy-Bosse, B.L.; Lesinski, G.B.; Jaime-Ramirez, A.C.; Benninger, K.; Khan, M.; Kuppusamy, P.; Guenterberg, K.; Kondadasula, S.V.; Chaudhury, A.R.; La Perle, K.M.; et al. Myeloid-derived suppressor cell inhibition of the IFN response in tumor-bearing mice. Cancer Res. 2011, 71, 5101-5110. [CrossRef]

133. Groth, C.; Hu, X.; Weber, R.; Fleming, V.; Altevogt, P.; Utikal, J.; Umansky, V. Immunosuppression mediated by myeloid-derived suppressor cells (MDSCs) during tumour progression. Br. J. Cancer 2019, 120, 16-25. [CrossRef]

134. Lu, C.; Redd, P.S.; Lee, J.R.; Savage, N.; Liu, K. The expression profiles and regulation of PD-L1 in tumor-induced myeloid-derived suppressor cells. Oncoimmunology 2016, 5, e1247135. [CrossRef]

135. Xiao, W.; Klement, J.D.; Lu, C.; Ibrahim, M.L.; Liu, K. IFNAR1 controls autocrine type I IFN regulation of PD-L1 expression in myeloid-derived suppressor cells. J. Immunol. 2018, 201, 264-277. [CrossRef]

136. Liang, H.; Deng, L.; Hou, Y.; Meng, X.; Huang, X.; Rao, E.; Zheng, W.; Mauceri, H.; Mack, M.; Xu, M.; et al. Host STING-dependent MDSC mobilization drives extrinsic radiation resistance. Nat. Commun. 2017, 8, 1736. [CrossRef]

137. Hong, E.H.; Cho, J.; Ahn, J.H.; Kwon, B.E.; Kweon, M.N.; Seo, S.U.; Yoon, B.I.; Chang, S.Y.; Ko, H.J. Plasmacytoid dendritic cells regulate colitis-associated tumorigenesis by controlling myeloid-derived suppressor cell infiltration. Cancer Lett. 2020, 493, 102-112. [CrossRef] [PubMed]

138. Zoglmeier, C.; Bauer, H.; Moerenberg, D.; Wedekind, G.; Bittner, P.; Sandholzer, N.; Rapp, M.; Anz, D.; Endres, S.; Bourquin, C. CpG blocks immunosuppression by myeloid-derived suppressor cells in tumor-bearing mice. Clin. Cancer Res. 2011, 17, 1765-1775. [CrossRef] [PubMed]

139. Shime, H.; Maruyama, A.; Yoshida, S.; Takeda, Y.; Matsumoto, M.; Seya, T. Toll-like receptor 2 ligand and interferon-gamma suppress anti-tumor $\mathrm{T}$ cell responses by enhancing the immunosuppressive activity of monocytic myeloid-derived suppressor cells. Oncoimmunology 2017, 7, e1373231. [CrossRef] [PubMed]

140. Greifenberg, V.; Ribechini, E.; Rossner, S.; Lutz, M.B. Myeloid-derived suppressor cell activation by combined LPS and IFN-gamma treatment impairs DC development. Eur. J. Immunol. 2009, 39, 2865-2876. [CrossRef] [PubMed]

141. Danelli, L.; Frossi, B.; Gri, G.; Mion, F.; Guarnotta, C.; Bongiovanni, L.; Tripodo, C.; Mariuzzi, L.; Marzinotto, S.; Rigoni, A.; et al. Mast cells boost myeloid-derived suppressor cell activity and contribute to the development of tumor-favoring microenvironment. Cancer Immunol. Res. 2015, 3, 85-95. [CrossRef]

142. Huang, B.; Pan, P.Y.; Li, Q.; Sato, A.I.; Levy, D.E.; Bromberg, J.; Divino, C.M.; Chen, S.H. Gr-1+CD115+ immature myeloid suppressor cells mediate the development of tumor-induced T regulatory cells and T-cell anergy in tumor-bearing host. Cancer Res. 2006, 66, 1123-1131. [CrossRef]

143. Burke, J.D.; Young, H.A. IFN- $\gamma$ : A cytokine at the right time, is in the right place. Semin. Immunol. 2019, 43, 101280. [CrossRef] [PubMed]

144. Medina-Echeverz, J.; Haile, L.A.; Zhao, F.; Gamrekelashvili, J.; Ma, C.; Métais, J.Y.; Dunbar, C.E.; Kapoor, V.; Manns, M.P.; Korangy, F.; et al. IFN-gamma regulates survival and function of tumor-induced CD11b+ Gr-1high myeloid derived suppressor cells by modulating the anti-apoptotic molecule Bcl2a1. Eur. J. Immunol. 2014, 44, 2457-2467. [CrossRef] [PubMed]

145. Andzinski, L.; Kasnitz, N.; Stahnke, S.; Wu, C.F.; Gereke, M.; von Köckritz-Blickwede, M.; Schilling, B.; Brandau, S.; Weiss, S.; Jablonska, J. Type I IFNs induce anti-tumor polarization of tumor associated neutrophils in mice and human. Int. J. Cancer 2016, 138, 1982-1993. [CrossRef] [PubMed]

146. Kalafati, L.; Kourtzelis, I.; Schulte-Schrepping, J.; Li, X.; Hatzioannou, A.; Grinenko, T.; Hagag, E.; Sinha, A.; Has, C.; Dietz, S.; et al. Innate Immune Training of Granulopoiesis Promotes Anti-tumor Activity. Cell 2020, 183, 771-785.e12. [CrossRef]

147. Jablonska, J.; Wu, C.F.; Andzinski, L.; Leschner, S.; Weiss, S. CXCR2-mediated tumor-associated neutrophil recruitment is regulated by IFN- $\beta$. Int. J. Cancer 2014, 134, 1346-1358. [CrossRef] [PubMed]

148. Andzinski, L.; Wu, C.F.; Lienenklaus, S.; Kröger, A.; Weiss, S.; Jablonska, J. Delayed apoptosis of tumor associated neutrophils in the absence of endogenous IFN- $\beta$. Int. J. Cancer 2015, 136, 572-583. [CrossRef] [PubMed] 
149. Wu, C.F.; Andzinski, L.; Kasnitz, N.; Kröger, A.; Klawonn, F.; Lienenklaus, S.; Weiss, S.; Jablonska, J. The lack of type I interferon induces neutrophil-mediated pre-metastatic niche formation in the mouse lung. Int. J. Cancer 2015, 137, 837-847. [CrossRef] [PubMed]

150. Raverdeau, M.; Cunningham, S.P.; Harmon, C.; Lynch, L. $\gamma \delta$ T cells in cancer: A small population of lymphocytes with big implications. Clin. Transl. Immunol. 2019, 8, e01080. [CrossRef] [PubMed]

151. Lawand, M.; Déchanet-Merville, J.; Dieu-Nosjean, M.C. Key Features of Gamma-Delta T-Cell Subsets in Human Diseases and Their Immunotherapeutic Implications. Front. Immunol. 2017, 8, 761. [CrossRef] [PubMed]

152. Gao, Y.; Yang, W.; Pan, M.; Scully, E.; Girardi, M.; Augenlicht, L.H.; Craft, J.; Yin, Z. $\gamma \delta$ T cells provide an early source of interferon $\gamma$ in tumor immunity. J. Exp. Med. 2003, 198, 433-442. [CrossRef]

153. He, W.; Hao, J.; Dong, S.; Gao, Y.; Tao, J.; Chi, H.; Flavell, R.; O’Brien, R.L.; Born, W.K.; Craft, J.; et al. Naturally activated V gamma 4 gamma delta $\mathrm{T}$ cells play a protective role in tumor immunity through expression of eomesodermin. J. Immunol. 2010, 185, 126-133. [CrossRef]

154. Takaoka, A.; Hayakawa, S.; Yanai, H.; Stoiber, D.; Negishi, H.; Kikuchi, H.; Sasaki, S.; Imai, K.; Shibue, T.; Honda, K.; et al. Integration of interferon- $\alpha / \beta$ signalling to $\mathrm{p} 53$ responses in tumour suppression and antiviral defence. Nature 2003, 424, 516-523. [CrossRef] [PubMed]

155. Kosciuczuk, E.M.; Mehrotra, S.; Saleiro, D.; Kroczynska, B.; Majchrzak-Kita, B.; Lisowski, P.; Driehaus, C.; Rogalska, A.; Turner, A.; Lienhoop, T.; et al. Sirtuin 2-mediated deacetylation of cyclin-dependent kinase 9 promotes STAT1 signaling in type I interferon responses. J. Biol. Chem. 2019, 294, 827-837. [CrossRef]

156. Saleiro, D.; Mehrotra, S.; Kroczynska, B.; Beauchamp, E.M.; Lisowski, P.; Majchrzak-Kita, B.; Bhagat, T.D.; Stein, B.L.; McMahon, B.; Altman, J.K.; et al. Central role of ULK1 in type I interferon signaling. Cell Rep. 2015, 11, 605-617. [CrossRef]

157. Deng, L.; Liang, H.; Xu, M.; Yang, X.; Burnette, B.; Arina, A.; Li, X.-D.; Mauceri, H.; Beckett, M.; Darga, T.; et al. STING-dependent cytosolic DNA sensing promotes radiation-induced Type I interferon-dependent antitumor immunity in immunogenic tumors. Immunity 2014, 41, 843-852. [CrossRef]

158. Ranoa, D.R.E.; Parekh, A.D.; Pitroda, S.P.; Huang, X.; Darga, T.; Wong, A.C.; Huang, L.; Andrade, J.; Staley, J.P.; Satoh, T.; et al. Cancer therapies activate RIG-I-like receptor pathway through endogenous non-coding RNAs. Oncotarget 2016, 7, $26496-26515$. [CrossRef] [PubMed]

159. Weichselbaum, R.R.; Ishwaran, H.; Yoon, T.; Nuyten, D.S.A.; Baker, S.W.; Khodarev, N.; Su, A.W.; Shaikh, A.Y.; Roach, P.; Kreike, B.; et al. An interferon-related gene signature for DNA damage resistance is a predictive marker for chemotherapy and radiation for breast cancer. Proc. Natl. Acad. Sci. USA 2008, 105, 18490-18495. [CrossRef]

160. Odnokoz, O.; Yu, P.; Peck, A.R.; Sun, Y.; Kovatich, A.J.; Hooke, J.A.; Hu, H.; Mitchell, E.P.; Rui, H.; Fuchs, S.Y. Malignant cell-specific pro-tumorigenic role of type I interferon receptor in breast cancers. Cancer Biol. Ther. 2020, 21, 629-636. [CrossRef]

161. Arslan, A.D.; Sassano, A.; Saleiro, D.; Lisowski, P.; Kosciuczuk, E.M.; Fischietti, M.; Eckerdt, F.; Fish, E.N.; Platanias, L.C. Human SLFN5 is a transcriptional co-repressor of STAT1-mediated interferon responses and promotes the malignant phenotype in glioblastoma. Oncogene 2017, 36, 6006-6019. [CrossRef]

162. Mojic, M.; Takeda, K.; Hayakawa, Y. The dark side of IFN- $\gamma$ : Its role in promoting cancer immunoevasion. Int. J. Mol. Sci. 2018, 19, 89. [CrossRef]

163. Shankaran, V.; Ikeda, H.; Bruce, A.T.; White, J.M.; Swanson, P.E.; Old, L.J.; Schreiber, R.D. IFN $\gamma$ and lymphocytes prevent primary tumour development and shape tumour immunogenicity. Nature 2001, 410, 1107-1111. [CrossRef]

164. Lüth, S.; Schrader, J.; Zander, S.; Carambia, A.; Buchkremer, J.; Huber, S.; Reifenberg, K.; Yamamura, K.I.; Schirmacher, P.; Lohse, A.W.; et al. Chronic inflammatory IFN- $\gamma$ signaling suppresses hepatocarcinogenesis in mice by sensitizing hepatocytes for apoptosis. Cancer Res. 2011, 71, 3763-3771.

165. Wang, W.; Green, M.; Choi, J.E.; Gijón, M.; Kennedy, P.D.; Johnson, J.K.; Liao, P.; Lang, X.; Kryczek, I.; Sell, A.; et al. CD8+ T cells regulate tumour ferroptosis during cancer immunotherapy. Nature 2019, 569, 270-274. [CrossRef] [PubMed]

166. Wang, Q.S.; Shen, S.Q.; Sun, H.W.; Xing, Z.X.; Yang, H.L. Interferon-gamma induces autophagy-associated apoptosis through induction of cPLA2-dependent mitochondrial ROS generation in colorectal cancer cells. Biochem. Biophys. Res. Commun. 2018, 498, 1058-1065. [CrossRef] [PubMed]

167. Zhang, M.; Huang, L.; Ding, G.; Huang, H.; Cao, G.; Sun, X.; Lou, N.; Wei, Q.; Shen, T.; Xu, X.; et al. Interferon gamma inhibits CXCL8-CXCR2 axis mediated tumor-associated macrophages tumor trafficking and enhances anti-PD1 efficacy in pancreatic cancer. J. Immunother. Cancer 2020, 8, e000308. [CrossRef] [PubMed]

168. Glasner, A.; Levi, A.; Enk, J.; Isaacson, B.; Viukov, S.; Orlanski, S.; Scope, A.; Neuman, T.; Enk, C.D.; Hanna, J.H.; et al. NKp46 Receptor-Mediated Interferon- $\gamma$ Production by Natural Killer Cells Increases Fibronectin 1 to Alter Tumor Architecture and Control Metastasis. Immunity 2018, 48, 107-119.e4. [CrossRef] [PubMed]

169. Chen, Y.; Hao, X.; Sun, R.; Wei, H.; Tian, Z. Natural Killer Cell-Derived Interferon-Gamma Promotes Hepatocellular Carcinoma Through the Epithelial Cell Adhesion Molecule-Epithelial-to-Mesenchymal Transition Axis in Hepatitis B Virus Transgenic Mice. Hepatology 2019, 69, 1735-1750. [CrossRef] [PubMed]

170. Zhuang, X.; Veltri, D.P.; Long, E.O. Genome-Wide CRISPR Screen Reveals Cancer Cell Resistance to NK Cells Induced by NK-Derived IFN- $\gamma$. Front. Immunol. 2019, 10, 2879. [CrossRef] [PubMed]

171. Freeman, A.J.; Vervoort, S.J.; Ramsbottom, K.M.; Kelly, M.J.; Michie, J.; Pijpers, L.; Johnstone, R.W.; Kearney, C.J.; Oliaro, J. Natural Killer Cells Suppress T Cell-Associated Tumor Immune Evasion. Cell Rep. 2019, 28, 2784-2794.e5. [CrossRef] 
172. Takeda, K.; Nakayama, M.; Hayakawa, Y.; Kojima, Y.; Ikeda, H.; Imai, N.; Ogasawara, K.; Okumura, K.; Thomas, D.M.; Smyth, M.J. IFN- $\gamma$ is required for cytotoxic T cell-dependent cancer genome immunoediting. Nat. Commun. 2017, 8, 14607. [CrossRef]

173. Singh, S.; Kumar, S.; Srivastava, R.K.; Nandi, A.; Thacker, G.; Murali, H.; Kim, S.; Baldeon, M.; Tobias, J.; Blanco, M.A.; et al. Loss of ELF5-FBXW7 stabilizes IFNGR1 to promote the growth and metastasis of triple-negative breast cancer through interferon- $\gamma$ signalling. Nat. Cell Biol. 2020, 22, 591-602. [CrossRef] [PubMed]

174. Thibaut, R.; Bost, P.; Milo, I.; Cazaux, M.; Lemaitre, F.; Garcia, Z.; Amit, I.; Breart, B.; Cornuot, C.; Schwikowski, B.; et al. Bystander IFN- $\gamma$ activity promotes widespread and sustained cytokine signaling altering the tumor microenvironment. Nature Cancer 2020, 1, 302-314. [CrossRef]

175. Zaidi, M.R.; Davis, S.; Noonan, F.P.; Graff-Cherry, C.; Hawley, T.S.; Walker, R.L.; Feigenbaum, L.; Fuchs, E.; Lyakh, L.; Young, H.A.; et al. Interferon- $\gamma$ links ultraviolet radiation to melanomagenesis in mice. Nature 2011, 469, 548-553. [CrossRef]

176. Ayers, M.; Lunceford, J.; Nebozhyn, M.; Murphy, E.; Loboda, A.; Kaufman, D.R.; Albright, A.; Cheng, J.D.; Kang, S.P.; Shankaran, V.; et al. IFN- $\gamma$-related mRNA profile predicts clinical response to PD-1 blockade. J. Clin. Investig. 2017, 127, 2930-2940. [CrossRef]

177. Benci, J.L.; Xu, B.; Qiu, Y.; Wu, T.J.; Dada, H.; Twyman-Saint Victor, C.; Cucolo, L.; Lee, D.S.M.; Pauken, K.E.; Huang, A.C.; et al. Tumor interferon signaling regulates a multigenic resistance program to immune checkpoint blockade. Cell 2016, 167, 1540-1554. [CrossRef]

178. Zou, W.; Wolchok, J.D.; Chen, L. PD-L1 (B7-H1) and PD-1 pathway blockade for cancer therapy: Mechanisms, response biomarkers, and combinations. Sci. Transl. Med. 2016, 8, 328rv4. [CrossRef] [PubMed]

179. Mo, X.; Zhang, H.; Preston, S.; Martin, K.; Zhou, B.; Vadalia, N.; Gamero, A.M.; Soboloff, J.; Tempera, I.; Zaidi, M.R. Interferon- $\gamma$ signaling in melanocytes and melanoma cells regulates expression of CTLA-4. Cancer Res. 2018, 78, 436-450. [CrossRef]

180. Spranger, S.; Spaapen, R.M.; Zha, Y.; Williams, J.; Meng, Y.; Ha, T.T.; Gajewski, T.F. Up- regulation of PD-L1, IDO, and T(regs) in the melanoma tumor microenvironment is driven by CD8(+) T cells. Sci. Transl. Med. 2013, 5, 200ra116. [CrossRef] [PubMed]

181. Zhang, X.; Zeng, Y.; Qu, Q.; Zhu, J.; Liu, Z.; Ning, W.; Zeng, H.; Zhang, N.; Du, W.; Chen, C.; et al. PD-L1 induced by IFN- $\gamma$ from tumor-associated macrophages via the JAK/STAT3 and PI3K/AKT signaling pathways promoted progression of lung cancer. Int. J. Clin. Oncol. 2017, 22, 1026-1033. [CrossRef]

182. Garcia-Diaz, A.; Shin, D.S.; Moreno, B.H.; Saco, J.; Escuin-Ordinas, H.; Rodriguez, G.A.; Zaretsky, J.M.; Sun, L.; Hugo, W.; Wang, X.; et al. Interferon receptor signaling pathways regulating PD-L1 and PD-L2 expression. Cell Rep. 2017, 19, 1189-1201. [CrossRef] [PubMed]

183. Hoekstra, M.E.; Bornes, L.; Dijkgraaf, F.E.; Philips, D.; Pardieck, I.N.; Toebes, M.; Thommen, D.S.; van Rheenen, J.; Schumacker, T.N.M. Long-distance modulation of bystander tumor cells by CD8+ T-cell-secreted IFN-gamma. Nat. Cancer 2020, 1, 291-301. [CrossRef] [PubMed]

184. Supplitt, S.; Karpinski, P.; Sasiadek, M.; Laczmanska, I. Current Achievements and Applications of Transcriptomics in Personalized Cancer Medicine. Int J. Mol. Sci. 2021, 22, 1422. [CrossRef] [PubMed]

185. Tang, W.; Wallace, T.A.; Yi, M.; Magi-Galluzzi, C.; Dorsey, T.H.; Onabajo, O.O.; Obajemu, A.; Jordan, S.V.; Loffredo, C.A.; Stephens, R.M.; et al. IFNL4- $\triangle$ G Allele Is Associated with an Interferon Signature in Tumors and Survival of African-American Men with Prostate Cancer. Clin. Cancer Res. 2018, 24, 5471-5481. [CrossRef] [PubMed]

186. Martin, D.N.; Boersma, B.J.; Yi, M.; Reimers, M.; Howe, T.M.; Yfantis, H.G.; Tsai, Y.C.; Williams, E.H.; Lee, D.H.; Stephens, R.M.; et al. Differences in the tumor microenvironment between African-American and European-American breast cancer patients. PLoS ONE 2009, 4, e4531. [CrossRef]

187. Budhwani, M.; Mazzieri, R.; Dolcetti, R. Plasticity of Type I interferon-mediated responses in cancer therapy: From anti-tumor immunity to resistance. Front. Oncol. 2018, 8, 322. [CrossRef]

188. Patel, S.J.; Sanjana, N.E.; Kishton, R.J.; Eidizadeh, A.; Vodnala, S.K.; Cam, M.; Gartner, J.J.; Jia, L.; Steinberg, S.M.; Yamamoto, T.N.; et al. Identification of essential genes for cancer immunotherapy. Nature 2017, 548, 537-542. [CrossRef]

189. Hamid, M.A.; Yao, X.; Waugh, C.; Rosendo-Machado, S.; Li, C.; Rostron, T.; Frankland, J.; Peng, Y.; Dong, T. Defective interferon gamma production by tumor-specific CD8+ T cells is associated with $5^{\prime}$ methylcytosine-guanine hypermethylation of interferon gamma promoter. Front. Immunol. 2020, 11, 310. [CrossRef] [PubMed]

190. Wong, L.H.; Krauer, K.G.; Hatzinisiriou, I.; Estcourt, M.J.; Hersey, P.; Tam, N.D.; Edmondson, S.; Devenish, R.J.; Ralph, S.J. Interferon-resistant human melanoma cells are deficient in ISGF3 components, STAT1, STAT2, and p48-ISGF3 $\gamma$. J. Biol. Chem. 1997, 272, 28779-28785. [CrossRef] [PubMed]

191. Xi, S.; Dyer, K.F.; Kimak, M.; Zhang, Q.; Gooding, W.E.; Chaillet, J.R.; Chai, R.L.; Ferrell, R.E.; Zamboni, B.; Hunt, J.; et al. Decreased STAT1 expression by promoter methylation in squamous cell carcinogenesis. J. Natl. Cancer Inst. 2006, 98, 181-189. [CrossRef]

192. Salerno, F.; Guislain, A.; Freen-Van Heeren, J.J.; Nicolet, B.P.; Young, H.A.; Wolkers, M.C. Critical role of post-transcriptional regulation for IFN- $\gamma$ in tumor-infiltrating T cells. Oncoimmunology 2018, 8, e1532762. [CrossRef] [PubMed]

193. Bhattacharya, S.; HuangFu, W.C.; Dong, G.; Qian, J.; Baker, D.P.; Karar, J.; Koumenis, C.; Diehl, J.A.; Fuchs, S.Y. Anti-tumorigenic effects of Type 1 interferon are subdued by integrated stress responses. Oncogene 2013, 32, 4214-4221. [CrossRef] [PubMed]

194. Huangfu, W.C.; Qian, J.; Liu, C.; Liu, J.; Lokshin, A.E.; Baker, D.P.; Rui, H.; Fuchs, S.Y. Inflammatory signaling compromises cell responses to interferon alpha. Oncogene 2012, 31, 161-172. [CrossRef] 
195. Ortiz, A.; Gui, J.; Zahedi, F.; Yu, P.; Cho, C.; Bhattacharya, S.; Carbone, C.J.; Yu, Q.; Katlinski, K.V.; Katlinskaya, Y.V.; et al. An Interferon-Driven Oxysterol-Based Defense against Tumor-Derived Extracellular Vesicles. Cancer Cell 2019, 35, 33-45.e6. [CrossRef]

196. Katlinskaya, Y.V.; Katlinski, K.V.; Yu, Q.; Ortiz, A.; Beiting, D.P.; Brice, A.; Davar, D.; Sanders, C.; Kirkwood, J.M.; Rui, H.; et al. Suppression of Type I Interferon Signaling Overcomes Oncogene-Induced Senescence and Mediates Melanoma Development and Progression. Cell Rep. 2016, 15, 171-180. [CrossRef] [PubMed]

197. Gao, J.; Shi, L.Z.; Zhao, H.; Chen, J.; Xiong, L.; He, Q.; Chen, T.; Roszik, J.; Bernatchez, C.; Woodman, S.E.; et al. Loss of IFN- $\gamma$ Pathway Genes in Tumor Cells as a Mechanism of Resistance to Anti-CTLA-4 Therapy. Cell 2016, 167, 397-404. [CrossRef] [PubMed]

198. Zaretsky, J.M.; Garcia-Diaz, A.; Shin, D.S.; Escuin-Ordinas, H.; Hugo, W.; Hu-Lieskovan, S.; Torrejon, D.Y.; Abril-Rodriguez, G.; Sandoval, S.; Barthly, L.; et al. Mutations Associated with Acquired Resistance to PD-1 Blockade in Melanoma. N. Engl. J. Med. 2016, 375, 819-829. [CrossRef]

199. Sade-Feldman, M.; Jiao, Y.J.; Chen, J.H.; Rooney, M.S.; Barzily-Rokni, M.; Eliane, J.P.; Bjorgaard, S.L.; Hammond, M.R.; Vitzthum, H.; Blackmon, S.M.; et al. Resistance to checkpoint blockade therapy through inactivation of antigen presentation. Nat. Commun. 2017, 8, 1136. [CrossRef]

200. Pötzl, J.; Roser, D.; Bankel, L.; Hömberg, N.; Geishauser, A.; Brenner, C.D.; Weigand, M.; Röcken, M.; Mocikat, R. Reversal of tumor acidosis by systemic buffering reactivates NK cells to express IFN-gamma and induces NK cell-dependent lymphoma control without other immunotherapies. Int. J. Cancer 2017, 140, 2125-2133. [CrossRef] 